\title{
Traditions and innovations: versatility of copper and tin bronze making recipes in Iron Age Emporion (L'Escala, Spain)
}

\author{
Julia Montes-Landa ${ }^{1}$ (1) - Ignacio Montero-Ruiz ${ }^{2}$. Pere Castanyer Masoliver ${ }^{3} \cdot$ Marta Santos Retolaza $^{3}$. \\ Joaquim Tremoleda Trilla ${ }^{3} \cdot$ Marcos Martinón-Torres $^{4}$ (D)
}

Received: 3 January 2020 / Accepted: 11 May 2020 / Published online: 1 June 2020

(C) The Author(s) 2020

\begin{abstract}
Established around 575 BC, Emporion was a Greek colonial enclave in north-east Iberia and hence constitutes a good context to study Mediterranean innovations and their adaptation with indigenous technologies. Here, we present an analytical study of the archaeometallurgical assemblage from a workshop context dated to the first occupational moment of Emporion's Neapolis (second half of the sixth century BC), including slag and technical ceramics. We aimed at reverse engineering the copper and tin bronze metallurgical technologies at the site. The results allow the identification of copper smelting and melting, and a variety of bronze alloying techniques, together with iron smelting and forging. The use of Fe-rich copper ores with $\mathrm{BaO}, \mathrm{ZnO}$ and $\mathrm{PbO}$ impurities is consistent with the exploitation of local sources, preceding the diversification of raw materials documented for later phases. The co-occurrence of co-smelting, cementation and co-melting as bronze making technologies is discussed with reference to parameters of efficiency and cost-effectiveness and contextualised in the broader colonial interaction, providing pointers for future comparative work and discussion. The early use of metallic tin for bronze production at the site supports a Mediterranean origin for this innovation in Iberia.
\end{abstract}

Keywords Iron Age $\cdot$ Copper $\cdot$ Bronze $\cdot$ Technology $\cdot$ Archaeometallurgy $\cdot$ Slag $\cdot$ Innovation

\section{Introduction}

The archaeological site of Empúries is located in the north-eastern part of the Iberian Peninsula. The site comprises the original Greek colonial settlement (Emporion), established in the sixth century $\mathrm{BC}$, and an adjacent Roman city (Emporiae) founded centuries later. The Greek enclave was founded by Phocaeans traders probably coming from Massalia in $\sim 575$ BC (Fig. 1). Favoured by its location by the sea and the natural harbour shaped

Julia Montes-Landa

jm2219@cam.ac.uk

Ignacio Montero-Ruiz

ignacio.montero@cchs.csic.es

Pere Castanyer Masoliver

pcastanyer@gencat.cat

Marta Santos Retolaza

msantosr@gencat.cat

Joaquim Tremoleda Trilla

jtremoleda@gencat.cat in the coastline, Emporion's main original role was commercial. It had good access to the maritime routes connecting the eastern and southern coast of the Iberian Peninsula as well as to the inner territories through the Ter and Fluviá river valleys (Mar and Ruiz de Arbulo 1993; Aquilué et al. 2010; Castanyer et al. 2009-2011; Santos et al. 2013; Castanyer et al. 2017). An ancient river estuary no longer existent was also located to the North of the city, which facilitated access to the inner lands (Castanyer et al. 2017).

Marcos Martinón-Torres m.martinon-torres@arch.cam.ac.uk

1 Department of Archaeology, University of Cambridge, Henry Wellcome Building, Fitzwilliam Street, Cambridge CB2 1QH, UK

2 Instituto de Historia-CSIC, c/Albasanz 26-28, 28037 Madrid, Spain

3 Museu d'Arqueologia de Catalunya-Empúries, c/Puig i Cadafalch, 17130 L'Escala, Spain

4 Department of Archaeology, University of Cambridge, Downing Street, Cambridge CB2 3ER, UK 
Fig. 1 Map showing the location of Emporion, Massalia and Phocaea

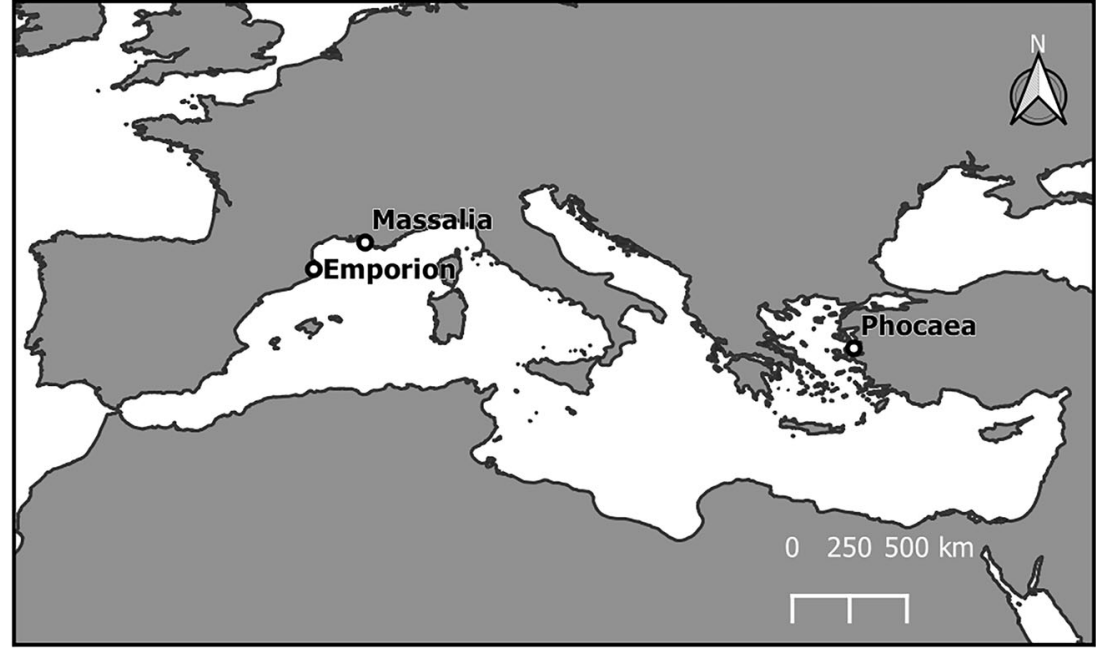

The first Greek settlement was originally located on a small promontory separated from the coast. However, this promontory is now part of the mainland as a result of natural landscape transformations (Nieto et al. 2005). This archaic Greek nucleus lays over an indigenous settlement with two occupational phases: an earlier one between the tenth and nineteenth centuries BC (Late Bronze Age, LBA) and a later one from the seventh century BC onwards (Iron Age, IA) (Santos Retolaza 2007; López Cachero 2007). This area of the Greek city was referred to by Strabo (III:4,8) as Palaiapolis (old city). The current town of Sant Martí d'Empúries sits over it. During the second half of the sixth century $\mathrm{BC}$, the site expanded into the mainland area to the South, and a new urban nucleus was developed, currently known as Neapolis (new city). For centuries, both areas of the Greek city were inhabited simultaneously and functioned as a single political unit (Mar and Ruiz de Arbulo 1993).

By the time of the Greek arrival, the indigenous populations had developed well-established occupational patterns in the surrounding area. They controlled local resources and maintained exchange routes with the Phoenician communities of the southern Iberian Peninsula, as suggested by imported goods (Castanyer et al. 2017). The first Mediterranean goods found in the indigenous settlement of Empúries can be dated back to the beginning of the IA (seventh century BC) (Santos et al. 2013). By the beginning of the sixth century BC, social stratification was being progressively consolidated locally, as illustrated by the Vilarena cemetery (Santos Retolaza 2003; Aquilué et al. 2012). Indigenous aristocracies located near the coast would have been based on the control of exchange and commercial routes, which were directly influenced by the Mediterranean contacts, first Phoenician and later Greek. At the same time, inland groups would have relied on controlling the exploitation and/or distribution of key resources (López Cachero 2007). The Greeks took advantage of the pre-existing social structure, the already established indigenous trade routes and the strategic geographical position of the indigenous settlement that was well connected and controlled the harbour. They contributed to the consolidation of these factors and integrated the area into the Mediterranean exchange system. However, during the initial occupational phases, the direct influence of Emporion within the surrounding indigenous societies is still barely perceptible (Santos Retolaza 2003; Aquilué et al. 2010).

This paper presents the characterisation of the earliest metallurgical remains related to copper and tin bronze manufactured at the site. These finds come from the first occupational layers of the Neapolis, excavated recently (Aquilué et al. 2011; Santos et al. 2013; Castanyer et al. 2009-2011; Castanyer et al. 2015). These were dated by typological associations between the second half of the sixth and the beginning of the fifth century BC. The assemblage studied is composed of slag remains associated with copper and tin bronze as well as technical ceramics and combustion structures. The study also included an appraisal of the ferrous metallurgical remains (found in the same contexts), which identified both smelting and smithing remains, but these results are not reported here (Montes-Landa 2017).

We aim to understand through reverse engineering the extractive techniques and the processes of both copper and bronze production. Of special importance is the characterisation of the different alloying methods for bronze manufacture through elemental analysis and observation of microstructures. Our finds are contextualised in the broader questions that are relevant to a renewed research interest in prehistoric bronze production and colonisation processes: evolution and transmission of technical knowledge, bronze alloying innovations, raw material acquisition, etc. We offer a tentative costeffectiveness explanation for the co-existence of several alloying methods in the same production contexts and outline a strategy and theoretical framework to validate our work and promote comparative studies. Our analyses offer the first detailed picture of the development of bronze production in Iron Age north-eastern Iberia. 


\section{Copper and tin bronze production techniques: Iberia is different}

A key peculiarity of the Iberian archaeometallurgical record is that, from the beginning of extractive copper metallurgy in the Chalcolithic and until Roman times, crucible smelting is the predominant system. Some examples include the Chalcolithic (third millennium $\mathrm{BC}$ ) crucible fragments from Almizaraque and Las Pilas (Rovira and Renzi 2017; Müller et al. 2004; Murillo-Barroso et al. 2017), the samples from several sites reported by Rovira (2007) and dated from the Early Bronze Age (EBA) (2300-1300 BC) to Roman times (first millennium $\mathrm{AC}$ onwards), as well as crucibles from the IA hillforts (eighth century BC until Roman times) of La Corona de Corporales, el Castrelín de San Juan de Paluezas and El Castru, among others (Farci et al. 2017; Fernandez-Posse et al. 1993). There is evidence for the deliberate production of these technical ceramics from the EBA, as shown in the presence of pouring spout and grip handles that are absent in other ceramics (Soriano and Escanilla 2016).

Working temperatures around $1100-1200{ }^{\circ} \mathrm{C}$ and variable reducing conditions are typical of crucible smelting. Metal droplets were recovered by crushing the generally immature, poorly reacted slag usually attached to the reaction vessel and later melted in a crucible to obtain the liquid metal that was cast (Milton et al. 1976; Rovira and Renzi 2017). This process involved great losses of mineral and charcoal and it was therefore not very efficient, but it covered the necessities of the local communities. To increase production, the number of operations was multiplied rather than enlarging the reaction vessels (Gómez Ramos 1996).

The earliest evidence for tin bronze production in Iberian comes from the North-east and is dated to the beginning of EBA (2300-1300 BC), as shown by the evidence at Bauma del Serrat del Pont (Alcalde et al. 1998). Bronze technology was most likely introduced from Southern France (Renzi 2013; Soriano 2013).

There are several ways of producing tin bronzes (Table 1), all of them involving crucibles and documented in Iberia. All of them required sufficiently reducing conditions and high temperatures but presumably had different costs, benefits and efficiency, in addition to potentially denoting different degrees of technical understanding and/or lines of knowledge transmission.

Identifying the specific technique employed for the production of bronze based on the analysis of metallurgical remains can therefore provide an interesting starting point to elucidate choices, constraints and learning traditions, as well as documenting the inception of innovations. In the last decade, several teams internationally have focused their efforts on the study of bronze making remains. Challenging assumptions that the alloying of pure metals would have been predominant in Prehistory, their investigations show that cementation was used in Bronze and/or IA sites in Thailand (Murillo-Barroso et al. 2010), the South Caucasus (Erb-Satullo et al. 2015), Portugal (Figueiredo et al. 2010), Britain (Nothover 1987) and Spain (Rodríguez Díaz et al. 2001; Rovira 2007; Renzi et al. 2008). Moreover, the combination of different alloying methods in the same site has been documented at LBA PiRamesses (Egypt) (Rademakers et al. 2018) and several Iberian sites (Farci et al. 2017; Renzi 2013). Also worth noting is the experimental study by Rademakers and Farci (2018), which provides useful reference materials for the identification of archaeological remains.

The Iberian region presents a complex panorama (Table 2). Unintentional natural alloying was taking place at Bauma del Serrat del Pont (Girona) during the third millennium BC (Alcalde et al. 1998; Rovira and Montero 2003; Rovira and Renzi 2017). Soon after that, during the EBA (2300-1300 $\mathrm{BC}$ ), the earliest evidence of co-smelting in Iberia is documented at the same site (Rovira and Montero 2003) and at Santa María de Matallana (Rovira 2007). By the end of the LBA (1300-650 BC), cementation appears in the archaeological record and it is consolidated over centuries. However, cosmelting remains common and is not superseded by the new technology. As a peculiar case in point, we can mention the finds from El Castru (Asturias) dated between the fifth and fourth centuries BC (Late Iron Age), where evidence of cosmelting and cementation appeared together in the same production contexts (Farci et al. 2017).

During IA-I (650-550 BC), the so-called Orientalising influence from the Eastern Mediterranean is perceptible in several traits and technologies in the southern Iberian territory, including a new way of making bronzes documented at the

Table 1 Different techniques used to produce a tin bronze alloy in antiquity (Pigott et al. 2003; Rademakers et al. 2018; Renzi 2013; Rovira 2007; Rovira 2009; Rovira and Montero 2003; Rovira and Montero-Ruiz 2013; Soriano 2013)

\begin{tabular}{lllll}
\hline Technique & Intentional & Cu state & Sn state & Control of result \\
\hline Natural alloying & No & Mineral (polymetallic Cu-Sn ore) & Mineral (polymetallic Cu-Sn ore) & Poor \\
Co-smelting & Yes & Mineral & Mineral (cassiterite) & Poor \\
Cementation & Yes & Metallic & Mineral (cassiterite) & Fair \\
Co-melting & Yes & Metallic & Metallic & Good \\
Re-melting/recycling & Yes & Metallic (bronze scrap) & Metallic (bronze scrap) and/or mineral (cassiterite) & Fair \\
\hline
\end{tabular}


Table 2 Iberian sites where tin bronze slags and/or technical ceramics have been analysed and the alloying process/processes identified in each case. The term 'Orientalising' is used for samples from contexts with evidence of Mediterranean influence based on complementary typological studies of other materials

\begin{tabular}{|c|c|c|c|}
\hline Site & Chronology & Process & Reference \\
\hline Bauma del Serrat del Pont (Girona) & Chalcolithic-EBA EBA & $\begin{array}{l}\text { Natural alloying } \\
\text { Co-smelting }\end{array}$ & $\begin{array}{l}\text { Alcalde et al. 1998; Rovira } \\
\text { and Montero } 2003\end{array}$ \\
\hline Santa María de Matallana (Valladolid) & EBA & Co-smelting & Rovira 2007 \\
\hline Cerro de San Cristóbal (Cáceres) & LBA & Cementation & Rodríguez Díaz et al. 2001 \\
\hline Castro de Senhora da Guia de Baiões (Viseu, Portugal) & LBA-EIA & Co-smelting? & Figueiredo et al. 2010 \\
\hline Las Camas (Madrid) & LBA-EIA & Co-smelting & Rovira 2007 \\
\hline Castro de Gusendo de los Oteros (León) & LBA-EIA & Cementation & Rovira 2007 \\
\hline El Castru (Asturias) & IA & $\begin{array}{l}\text { Co-smelting } \\
\text { Cementation }\end{array}$ & Farci et al. 2017 \\
\hline Sant Jaume-Mas d'en Serra (Tarragona) & IA-I (Orientalising) & Cementation & Rovira 2007 \\
\hline L'Illa d'en Reixac (Girona) & IA (Orientalising) & Co-smelting or cementation & Rovira Hortalà 1993 \\
\hline La Rebanadilla (Málaga) & IA-I (Orientalising) & Co-smelting & Renzi 2013 \\
\hline El Carambolo (Seville) & IA-I (Orientalising) & Cementation & Rovira 2007 \\
\hline Emporion & IA-I (Orientalising) & Cementation & Renzi et al. 2008 \\
\hline Carmona (Seville) & IA-I (Orientalising) & Co-melting & Rovira 2007 \\
\hline \multirow[t]{2}{*}{ La Fonteta (Alicante) } & IA-I (Orientalising) & $\begin{array}{l}\text { Co-smelting } \\
\text { Cementation }\end{array}$ & Renzi 2013; Rovira 2007 \\
\hline & & Co-melting & \\
\hline
\end{tabular}

sites of La Fonteta and Carmona: the co-melting of metallic copper and tin. However, at La Fonteta, evidence of cosmelting and cementation has also been reported in contemporaneous archaeological contexts (Renzi 2013; Rovira 2007). The evidence from these two sites would seem to lend support to the hypothesis that the use of co-melting for manufacturing tin bronze derived from Mediterranean contacts, specifically from the Phoenicians (Rovira 2007).

Our analyses of Emporitan archaeometallurgical finds sought to characterise the range of copper-based technologies employed during the early phase of the site existence, with particular emphasis on bronze making techniques. If co-melting was documented, this would support the proposition that the introduction of this innovation might also be related to Greek presence and not just to the Phoenicians. In addition, given that initial analytical work at the site reported a bronze slag that probably resulted from a cementation operation (Renzi et al. 2008), we expanded the sample to test whether several techniques might have co-existed at the site. Given that three different techniques had been documented at La Fonteta (an equivalent Phoenician site to Greek Emporion), our analyses could help verify whether the indigenous alloying techniques of cementation and co-smelting, developed since Bronze Age and long before Mediterranean influence was perceptible in the area (see above), persisted together with the new alloying technique. More generally, with a larger dataset from a single site, we are in a much better position to start theorising about possible explanations for this variability in the same production contexts.

Last but not least, it is important to contextualise this work against the background of the relatively scarce evidence for metallic tin extraction in prehistoric Iberia. The earliest evidence of tin smelting in the Iberian Peninsula was discovered at Castro de Carvalhelhos (Portugal), a site occupied from the second century BC until the first century AC (Figueiredo et al. 2018; Renzi 2013; Rovira 2007). The only other known examples of early metallic tin objects in Iberia are a tin sheet with perforations found at Huelva in a context dated to the ninth century BC (González de Canales et al. 2006) and three tin beads from Mongofre Nou (Menorca) dated between the ninth and eight centuries BC (Montero Ruíz et al. 2005). At the mining area of Cerro de San Cristóbal (Cáceres), the evidence confirmed the exploitation of cassiterite from the LBA at least (Rodríguez Díaz et al. 2001), and both cassiterite and tin ingots have been found at Bajo de la Campana shipwreck, dated to the late seventh century BC (Polzer and Pinedo Reyes 2009; Renzi 2013; Roldán Bernal et al. 1995). Moreover, metallic tin has been found at Cala Sant Vicenç shipwreck too, dated to the sixth century BC (Rovira 2008; Rovira et al. 2008). Based on the evidence available, we cannot rule out the possibility that the earliest metallic tin used for bronze alloying was obtained through the Mediterranean market, especially in the coastal areas. Similarly, we cannot verify conclusively whether tin was exploited for self-supply or export. These questions highlight the importance of understanding 
why mineral tin might have been chosen instead of metallic tin when manufacturing bronze objects.

Although our study at Emporion will engage with these important questions, we acknowledge that many of the issues we raise are broad in scope and should be addressed from wider comparative perspectives, and integrating several lines of evidence. However, detailed case studies are necessary to provide a solid foundation for nuanced discussion. The production of tin bronzes and the technological and socioeconomical dynamics behind the selection of specific steps in the bronze chaines opératoires is a research topic of growing interest, and our discussion presents some concrete ideas and pointers for future work.

\section{The archaeological contexts}

The materials studied come from two different contexts at the Neapolis: a workshop and a rubbish dump. These contexts were excavated by the Archaeological Museum of Catalonia-Empúries between 2005 and 2015.

Context N-15 is located at the Neapolis, below the nowadays visible Hellenistic Stoa. Excavations in this area (Castanyer et al. 2009-2011; Santos et al. 2013; Castanyer et al. 2015) documented the first occupational phases of the Neapolis. Here, a metallurgical workshop was uncovered, with several phases dated between the second half of the sixth century and the early fifth century BC. On the oldest level of sector B, a small iron furnace was excavated together with a large oval pit with copper/bronze scrap metal mixed with burnt charcoal and sediment in it that may indicate recycling activities (Fig. 2 a and b). Later levels show different arrangements of pits dug in the ground ( $\sim 40 \mathrm{~cm}$ diameter) (Fig. $2 \mathrm{c}$ and d). Some of the pits had plano-convex iron slags in them that could be related to iron forging activities whereas other pits could have been used for copper-based activities. On the earliest layers of sector A, a larger combustion structure was characterised as a non-tapping bloomery iron furnace (Fig. 3).

Samples 11146-2 and 11109-1 (see below), recovered from context $\mathrm{N}-15$, are not directly related to the aforementioned structures excavated in 2012. They were found in 2015 at contemporaneous archaeological layers located a short distance to the North of the structures previously described. These layers are also dated to the third-quarter of the sixth century BC. Therefore, they must be also related to the first production phase of the metallurgical workshop.

Context N-22, excavated in 2008, is at the north-western area of the Neapolis, where the access ramp that connected the natural harbour with the Neapolis was located. At the western end, an artificial terrace was built on the bedrock between the end of the sixth century $\mathrm{BC}$ and the beginning of the fifth century BC. The terrace was formed by two perpendicular walls containing a single 1-m deep stratum full of discarded materials used to flatten its surface. Samples 1311-A2, 1311B2 and 1311-B4/5 (see below) come from this thick layer, while samples 1171-4, 1171-2, 1215-4 and 1215-5 come from other strata identified during the excavation of this area. The open space at the top of the terrace corresponds to a first westward extension of the nucleus. It was subsequently used as a worshiping and ritual area, as suggested by votive offerings and related finds recovered from it (Castanyer et al. 2009-2011; Santos et al. 2013; Castanyer et al. 2015).

Fig. 2 Context $\mathrm{N}-15$, sector B. a Phase 1, general view. b Phase 1, detail of the (1) slag pit of the iron bloomery furnace, (2) tunnel for inserting the tuyère and (3) oval pit where copper/bronze scrap metal was found. c Phase 2, view of the location of (4) a quadrangular compacted clay structure and (5) an oval pit. d Phase 3, view of several pits dug in the ground. Note that the space is no longer compartmentalised. (Photos: MAC-Empúries)

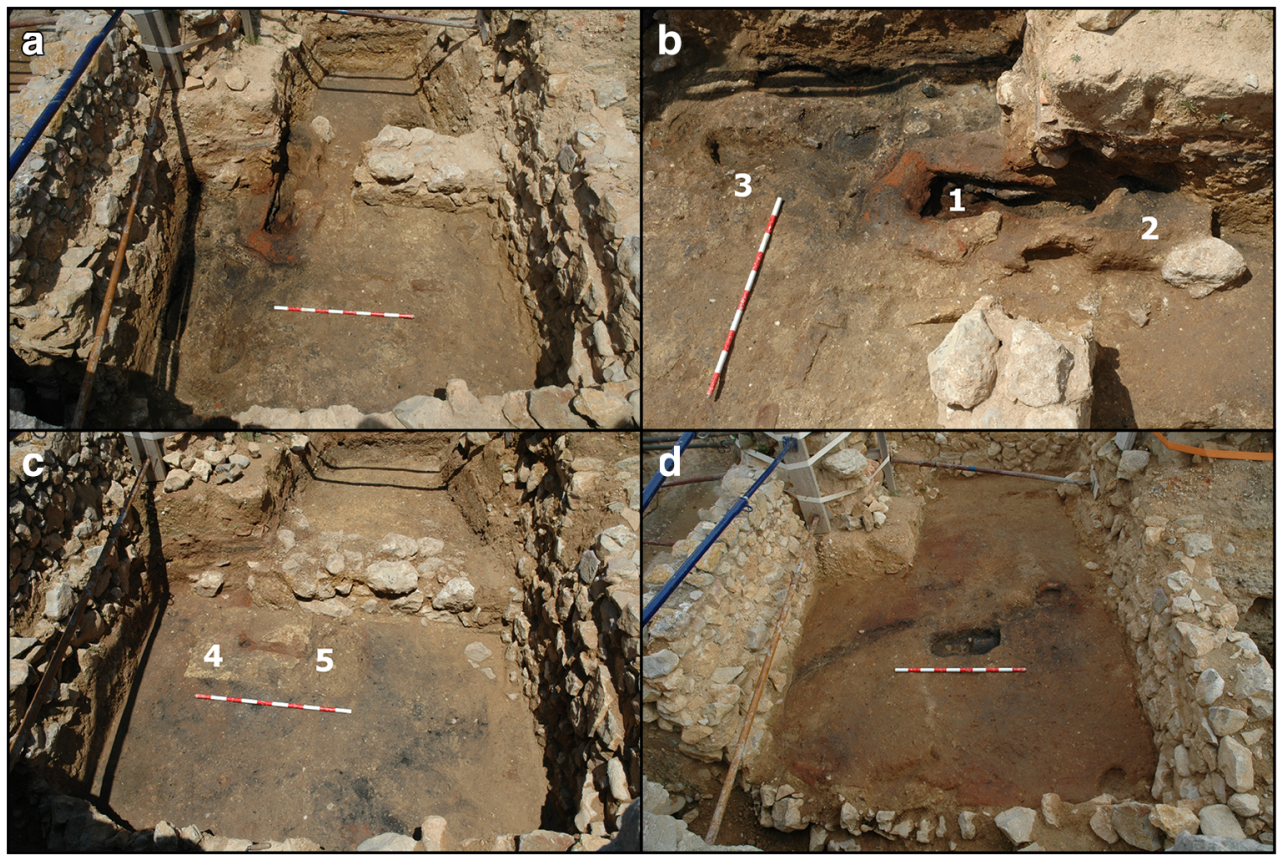




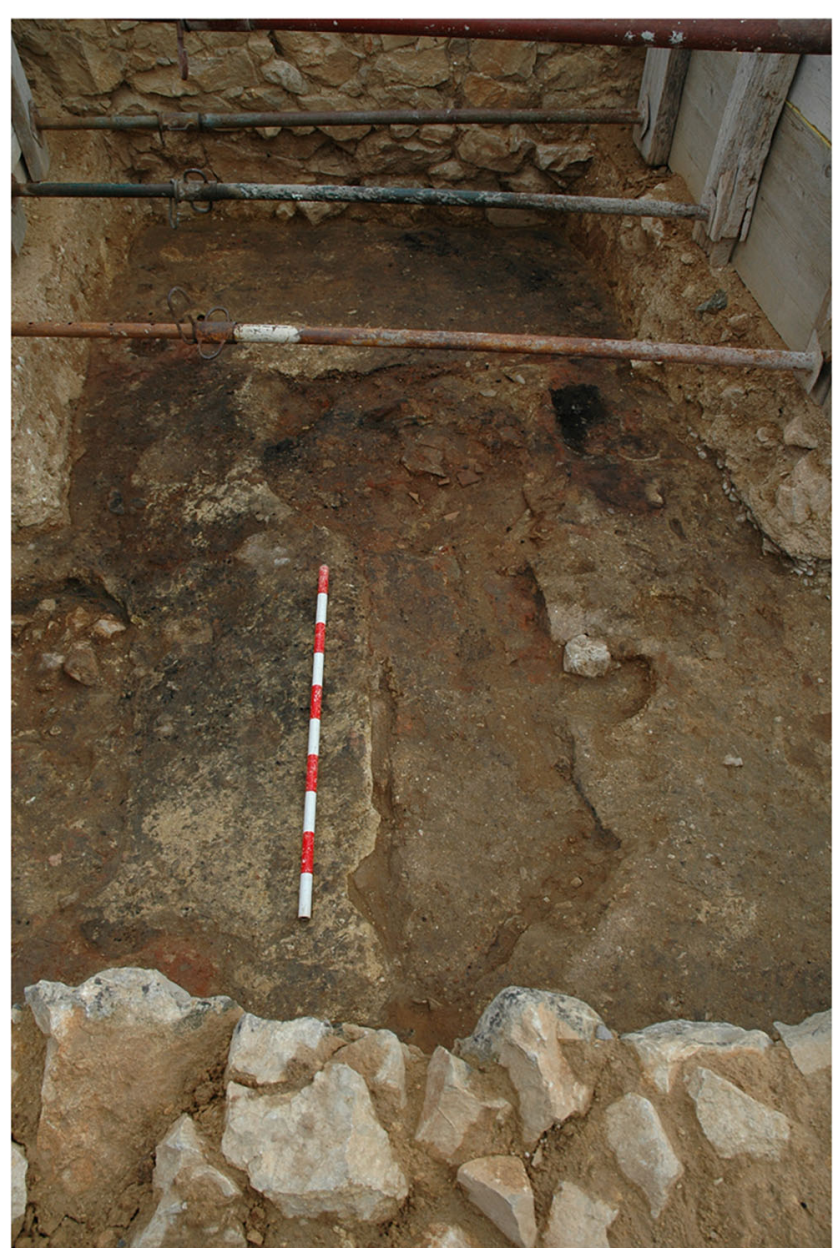

Fig. 3 General view of context N-15, sector A, phase 1. Circular combustion structure dug in the ground where numerous iron slag lumps were found. Note the rectangular area connected to this structure. (Photo: MAC-Empúries)

When considering the spatial distribution of activities, within context $\mathrm{N}-15$, sector $\mathrm{B}$, we can see that copper-based activities are always identified next to iron production waste and structures. Nonetheless, sector A, where the large bloomery furnace is located, seems to be entirely dedicated to iron production. In context $\mathrm{N}-22$, iron by-products and copper-based by-products and objects appear mixed in the same stratum.

While all furnaces were related to iron metallurgy, the only structural remains directly associated with copper- and bronze-related activities are some fired clay remains attached to slag fragments. Early crucible smelting metallurgy often requires breaking the crucible to recover the metal. However, no crucibles were found at Emporion. Instead, "baked clay lining" fragments with a clear inner vitrified surface were recovered. This evidence is consistent with the abundant pits on the workshop floor (see above) and the clay lining of some of them. It is likely that the pits dug in the ground were directly used as very simple bowl furnaces (Gómez Ramos 1996). The operations would have occurred over the clay lining that was fired during the process. Subsequently, this pit lining would have been broken in order to recover the resulting metal, and producing the fragments collected during the archaeological excavations. The pits might have been used again with fresh clay lining layers. Smelting pits of this kind have been documented at other Iberian sites, such as Las Pilas and El Acequión (Fernández Miranda 1994; Murillo-Barroso et al. 2017), but these sites, unlike Emporion, also yielded crucible remains. However, it is possible that they might be at other unexcavated area of the settlement.

\section{Materials and methods}

The majority of the metallurgical assemblage is made up of relatively small slag nodules, ranging from 2 to $160 \mathrm{~g}$. Following an initial visual assessment, we carried out screening portable XRF (pXRF) analyses of 54 samples, trying to cover the macroscopic variability. These analyses were carried out using an Olympus Delta Premium with a Rh tube, operating at $40 \mathrm{kV}, 30 \mathrm{~s}$ for analysis, and using the Comptonnormalised 'Soils method'. These analyses confirmed the typical association of the smaller lumps with sharp fractures to non-ferrous metallurgy, in agreement with the suggestion that they were crushed to retrieve metal prills; larger slag cakes were associated with iron metallurgy (Fig. 4).

We then selected a subset (Table 3 ) of the copperbearing samples for invasive analyses, trying to cover compositional variability (namely, whether or not they had traces of tin) as well as typological diversity (e.g. presence of clay lining adhered) and representation of archaeological contexts.

Cross-sections of the selected specimens were mounted in epoxy resin, ground and polished flat using $\mathrm{SiC}$ and diamond paste down to $1 \mu \mathrm{m}$. Samples were latter observed under reflected plaine polarised (PPL) and cross-polarised light (XPL) using a Leica DM4500 P LED optical microscope (OM). The polished blocks were carbon coated and analysed under a scanning electron microscope (SEM-EDS). The machine used was a Philips XL30 ESEM equipped with an Oxford Instruments EDS detector and INCA software ( $20 \mathrm{kV}, 140 \mathrm{~s}$ acquisition time, $10 \mathrm{~mm}$ working distance). All SEM images in this paper were taken with a backscattered electron detector (BSE). The SEM-EDS was calibrated every 30 min with a pure cobalt standard. All the compositional results reported are at least $3 \sigma$ above the background. They are reported as percentage by weight (wt\%), with oxygen added by stoichiometry when values are presented as oxides. We therefore use simple oxide formulas when talking about chemical analyses, following established conventions, but not aiming to denote any specific mineral phase unless otherwise specified on the text. Analytical totals were low when 
Fig. 4 Some specimens recovered from Emporion representing the typical finds: Fe slag cake (top left), Cu-based slags (top right) and different views of the tuyère $1311 ; \mathrm{B} 4 / 5$ (bottom)

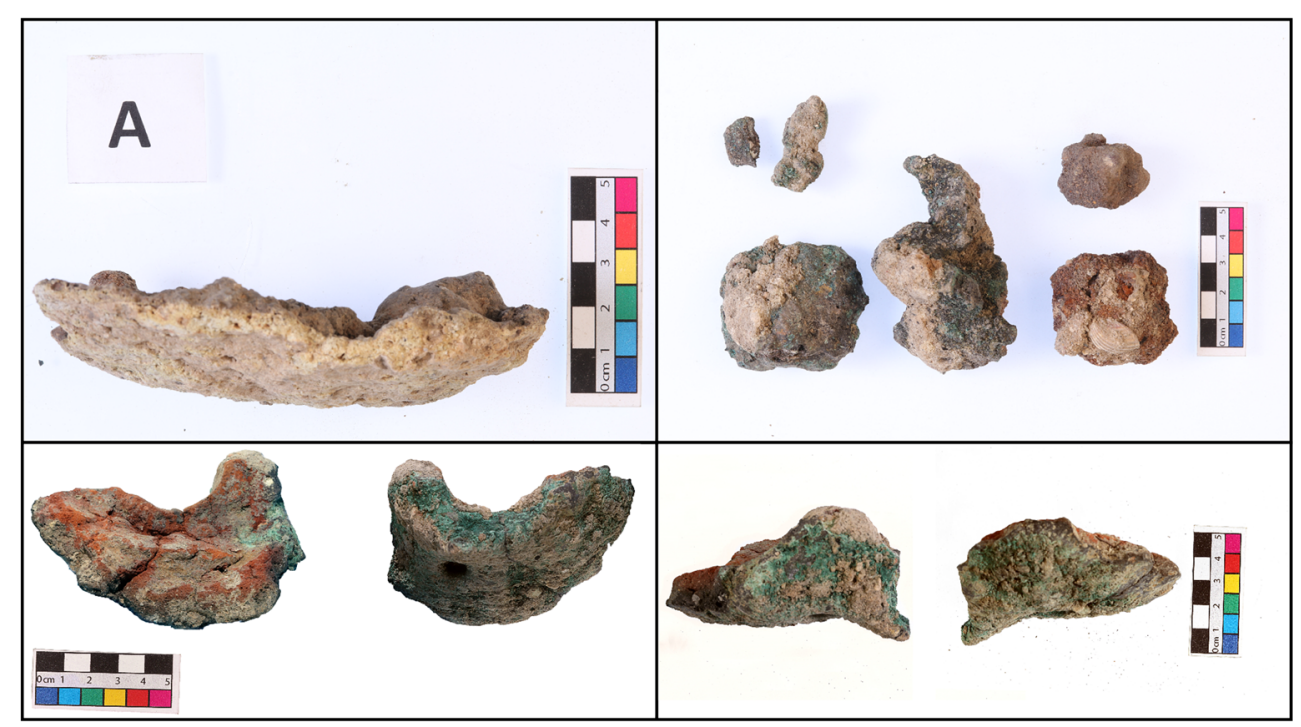

analysing ceramics, primarily given their higher porosity; results have been normalised to $100 \%$ to facilitate comparisons, but the original analytical totals are reported on the tables.

Indicative 'bulk' compositions and analyses of the glassy/ ceramic matrices reported are the result of a minimum of 3 area analyses. While for bulk compositions no specific components were avoided except very large pores, area analyses of glassy matrices avoided pores, metal prills, unreacted inclusions and distinct crystals. For the ceramic matrices, mineral inclusions were excluded together with as much large porosity as possible. Bulk compositions were taken at $\times 100$ magnifications, corresponding to an area of $1200 \times 950 \mu \mathrm{m}$. Given the very variable microstructure of the samples, it was not possible to apply a standardised area size for glassy and ceramic matrices analyses, so variable area sizes (always as large as feasible) were used for the sake of more representative results.

In order to make the descriptions of bronze slag microstructures clearer, when describing tin oxide crystals, we use the term 'euhedral needles' to refer both to needles of this shape and to the rhombohedral crystal shapes that result from the transversal sectioning of a euhedral needle. 'Elongated needles' is used to describe needle-like formations with circular cross-sections and the circular crystal shapes that result from their transversal sectioning.

\section{Results}

\section{Copper metallurgy}

Three slag lumps (samples 1215-4, 1215-5 and 11146-2) and one metallic droplet attached to a slag fragment (sample 1171-2) were related to copper metallurgy. Their glassy matrices composition showed two subgroups (Table 4): samples 1215-4 and 1171-2 show lower $\mathrm{Al}_{2} \mathrm{O}_{3}$ and $\mathrm{SiO}_{2}$ levels, higher $\mathrm{FeO}$ and $\mathrm{CuO}$ and detectable amounts of $\mathrm{ZnO}$ and $\mathrm{BaO}$; samples 11146-2 and 1215-5 have higher $\mathrm{Al}_{2} \mathrm{O}_{3}$ and $\mathrm{SiO}_{2}$, lower $\mathrm{FeO}$ and $\mathrm{CuO}$ and no detectable $\mathrm{ZnO}$ and $\mathrm{BaO}$. These two patterns correspond, respectively, to the subgroups identified as copper smelting and copper melting slag.
Table 3 Summary of samples selected for invasive analysis after pXRF screening. (*) Initially thought to be related to $\mathrm{Cu}$ metallurgy, but bronze-related after SEM-EDS analysis

\begin{tabular}{|c|c|c|c|}
\hline Sample & Context & Characterisation & Diagnostic elements \\
\hline $11146-2$ & $15-\mathrm{N}-15$ & Slag & $\mathrm{Cu}$ \\
\hline 11109-1 & $15-\mathrm{N}-15$ & Slag & $\mathrm{Cu}+\mathrm{Sn}$ \\
\hline 1311-A2 & $08-\mathrm{N}-22$ & Slag & $\mathrm{Cu}+\mathrm{Sn}$ \\
\hline 1311-B2 & $08-\mathrm{N}-22$ & Technical ceramic adhered to slag & $\mathrm{Cu}+\mathrm{Sn}$ \\
\hline $1215-4$ & $08-\mathrm{N}-22$ & Slag & $\mathrm{Cu}$ \\
\hline $1215-5$ & $08-\mathrm{N}-22$ & Slag & $\mathrm{Cu}$ \\
\hline $1171-2$ & $08-\mathrm{N}-22$ & Metallic droplet embedded in slag & $\mathrm{Cu}$ \\
\hline 1311-B4/5 & $08-\mathrm{N}-22$ & Tuyère & $\mathrm{Cu}+\mathrm{Sn}^{*}$ \\
\hline $1171-4$ & $08-\mathrm{N}-22$ & Slag & $\mathrm{Cu}+\mathrm{Sn}$ \\
\hline
\end{tabular}


Table 4 SEM-EDS mean compositions of the glassy matrices of copper slag

\begin{tabular}{|c|c|c|c|c|c|c|c|c|c|c|c|c|c|c|c|c|}
\hline ID & $\mathrm{Na}_{2} \mathrm{O}$ & $\mathrm{MgO}$ & $\mathrm{Al}_{2} \mathrm{O}_{3}$ & $\mathrm{SiO}_{2}$ & $\mathrm{P}_{2} \mathrm{O}_{5}$ & $\mathrm{Cl}$ & $\mathrm{K}_{2} \mathrm{O}$ & $\mathrm{CaO}$ & $\mathrm{TiO}_{2}$ & $\mathrm{MnO}$ & $\mathrm{FeO}$ & $\mathrm{CuO}$ & $\mathrm{ZnO}$ & $\mathrm{BaO}$ & $\mathrm{PbO}$ & Anal. total \\
\hline $1215-4$ & 1.3 & 1.8 & 7.8 & 45.8 & 0.7 & ND & 2.2 & 6.1 & 0.5 & 0.5 & 15.4 & 16.9 & 0.6 & 2.0 & 1.4 & 101.6 \\
\hline $1171-2$ & ND & 0.9 & 5.5 & 50.1 & 0.7 & 3.6 & 2.7 & 8.1 & ND & ND & 15.3 & 14.5 & 0.7 & 3.6 & ND & 97.0 \\
\hline $11146-2$ & 2.3 & 2.4 & 17.0 & 59.8 & 0.7 & ND & 4.0 & 4.2 & 0.9 & 1.0 & 7.3 & 1.2 & ND & ND & ND & 96.4 \\
\hline $1215-5$ & 2.2 & 1.1 & 15.1 & 61.4 & 1.9 & ND & 5.3 & 3.3 & 0.7 & ND & 1.6 & 8.8 & ND & ND & ND & 100.3 \\
\hline
\end{tabular}

$N D$ not detected

\section{Copper smelting}

The large metal prill in sample 1171-2 is nominally pure copper, with a slight $\mathrm{Cl}$ enrichment that is most likely postdepositional and facilitated by the proximity to the sea. It also contains small crystals of intergranular covellite $(\mathrm{CuS})$ with occasional $\mathrm{Sb}$ and $\mathrm{Pb}$. As for sample 1215-4, it contains numerous copper droplets too, often with significant Fe (up to $3.8 \mathrm{wt} \% \mathrm{Fe})$ and minor $\mathrm{S}$ and $\mathrm{Sn}(<0.7 \mathrm{wt} \% \mathrm{Sn})$.

The non-metallic slag matrix is in both cases an Al silicate with relatively high concentrations of $\mathrm{FeO}$ and $\mathrm{CuO}$, and moderate levels of $\mathrm{CaO}$. $\mathrm{ZnO}$ and $\mathrm{BaO}$ impurities are common in both specimens, and sample 1215-4 also has a minor presence of $\mathrm{PbO}$ (Table 4). This composition is consistent with their crystal structure, which is dominated by cuprite $\left(\mathrm{Cu}_{2} \mathrm{O}\right)$ droplets and delafossite $\left(\mathrm{CuFeO}_{2}\right)$ needles together with skeletal, tabular and idiomorphic magnetite $\left(\mathrm{Fe}_{3} \mathrm{O}_{4}\right)$ (Figs. 5 and 6). Some quartz inclusions were also found in sample 1215-4.

The low concentrations of any heavy elements other than copper in both the slag and the metal trapped within confirm that the product of these reactions would be unalloyed copper, and the levels of S, $\mathrm{Zn}, \mathrm{Sn}, \mathrm{Sb}, \mathrm{Ba}$ and $\mathrm{Pb}$ detected most likely reflect ore impurities rather than deliberate additions to the

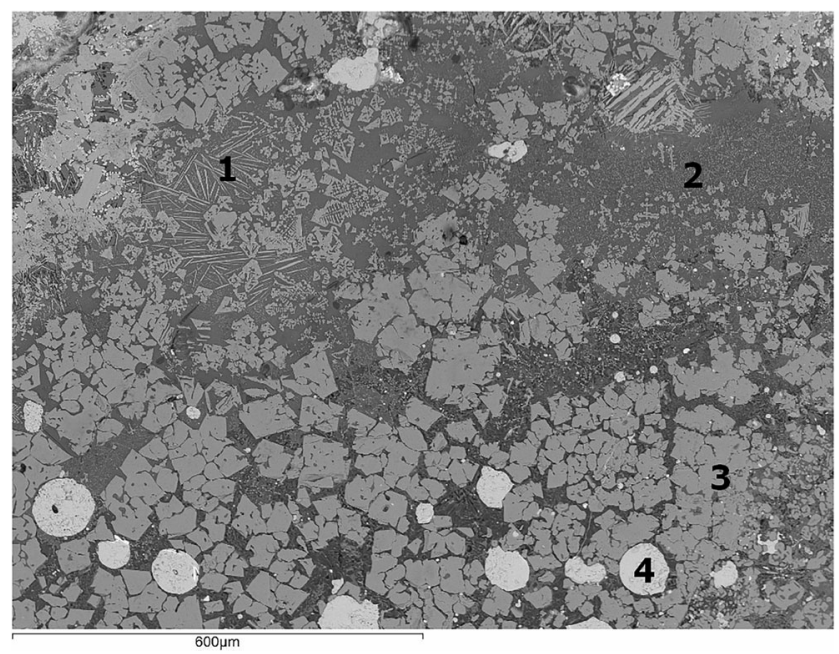

Fig. 5 BSE micrograph of sample 1171-2 showing the slag matrix with abundant delafossite needles (1), skeletal (2) and tabular (3) magnetite formations and cuprite prills $(4)$. (Scale $=600 \mu \mathrm{m})$ charge. The presence of cuprite and delafossite in slag is often taken as indicative of copper melting, as these phases can form from the oxidation of metallic copper (e.g. Bachmann 1982, p. 16). However, the co-occurrence of magnetite, delafossite and cuprite is common in the relatively immature crucible smelting slag that is typical of prehistoric Iberia, which resulted from a variable, only mildly reducing conditions and thus led to significant copper-rich oxide losses in the slag (e.g. Müller et al. 2004; Murillo-Barroso et al. 2017). The abundant magnetite clusters documented in some areas of the samples (Fig. 7) seem more consistent with partially decomposed Ferich ore/gangue materials (Hauptmann 2007, p. 171) than with the oxidation of metallic iron contained within the copper and thus support the proposition that minerals rather than metals were being processed here, leading to the formation of some Fe-rich copper metal particles as documented in 1215-4. In some areas of sample 1215-4, however, there are primary crystals of skeletal magnetite forming around a core of metallic copper that are clearly related to the oxidation of Fe-rich copper, hence confirming the variable and imperfect redox conditions (Fig. 6). In other areas, crystals of delafossite appear more concentrated around $\mathrm{Cu}$-rich nodules (Fig. 7); these structures confirm the genetic link between iron and copper, but it is harder to determine whether they represent the process

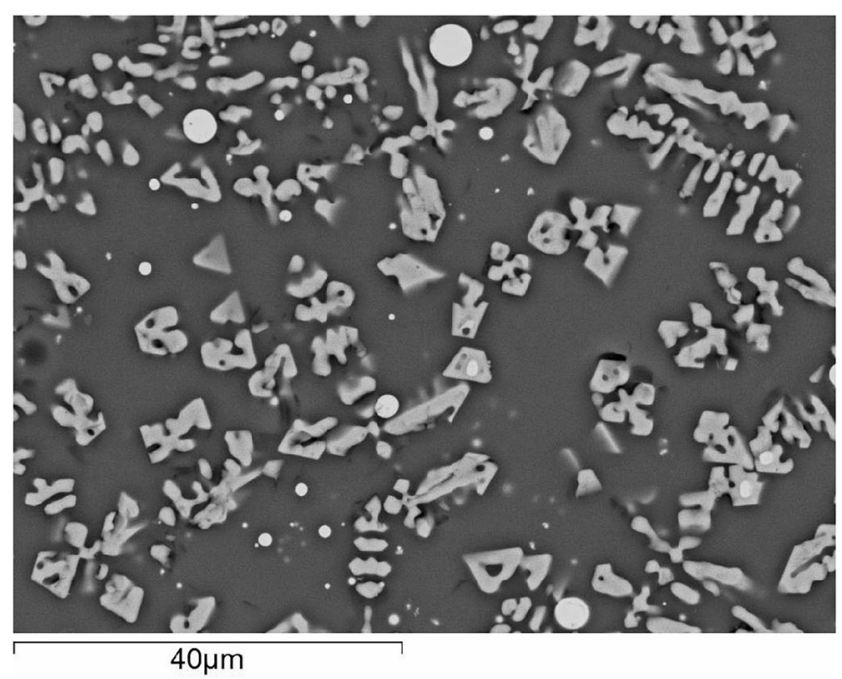

Fig. 6 BSE micrograph of sample 1215-4 showing skeletal magnetite formations and $\mathrm{Cu}$ droplets inside idiomorphic magnetite crystals 


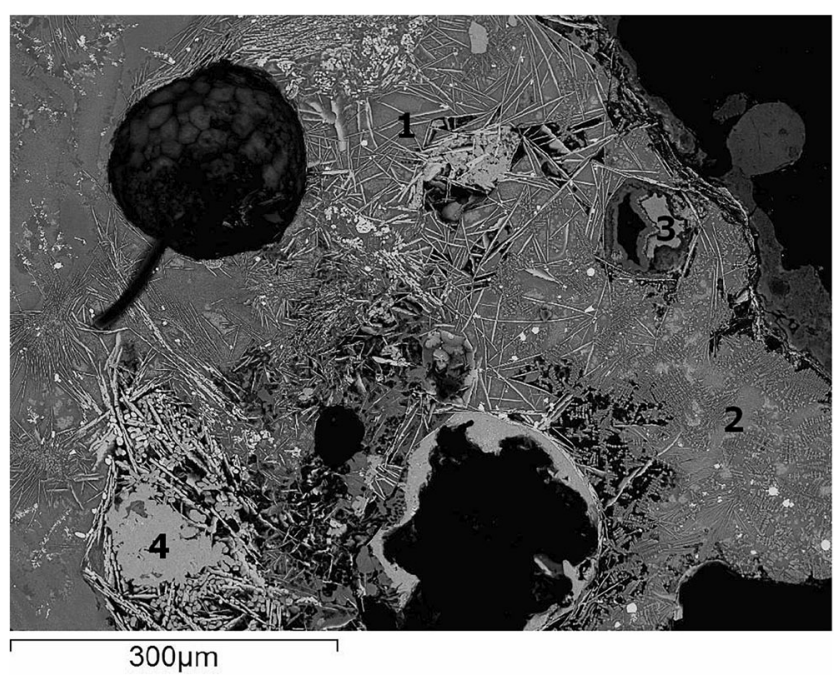

Fig. 7 BSE micrograph of sample 1215-4 showing an area where both delafossite (1) and skeletal magnetite (2) formations are together. $\mathrm{Cu}$ corrosion products (3) are concentrated around one of the pores, and a concentration of delafossite was located around a copper-rich nodule (4)

of reduction of a $\mathrm{Cu}-\mathrm{Fe}$ mineral or the oxidation of ferruginous copper metal.

All in all, we interpret these samples as resulting from the smelting of ferruginous copper minerals, which may also have carried some quartz gangue, in addition to other impurities. The smelting would have taken place under variable redox atmospheres that reached mildly reducing conditions $\left(\mathrm{pO}_{2}\right.$ $10^{-6}-10^{-5}$ at $1000-1200{ }^{\circ} \mathrm{C}$ ), resulting in the heterogeneous structures and high $\mathrm{Cu}$ losses noted. Delafossite is stable at $1150{ }^{\circ} \mathrm{C}$ (Rovira and Renzi 2017), and skeletal magnetite requires at least $1300^{\circ} \mathrm{C}$ to form (Renzi 2013), which together provide an indicative working temperature range for both samples. As typical of prehistoric Iberian smelting, it is unlikely that the ores were fluxed deliberately, as also indicated by the absence of fayalite.

\section{Copper melting}

Sample 11146-2 is predominantly a glassy $\mathrm{Al}$ silicate with a moderate Fe enrichment (7.3 wt\% FeO, Table 4). Although comparatively poor in $\mathrm{Cu}$ on average $(1.2 \mathrm{wt} \% \mathrm{CuO})$, some red areas can be distinguished under OM, caused by fine intergranular exsolution of cuprite (Fig. 8). SEM-EDS analyses of the metallic $\mathrm{Cu}$ droplets embedded within indicated consistent $\mathrm{Fe}$ presence (0.6-2.0 wt\%) with $\mathrm{S}$ impurities. No other Fe-bearing phases were found in the slag, so it is likely that the Fe enrichment of the glassy matrix occurred as a result of the re-oxidation of this element that entered the system with impure raw copper, in addition to some possible contribution from the clay. In fact, many quartz grains, shattered by thermal stress and partially dissolved, were found in clay-rich areas, often together with small zircon inclusions $\left(\mathrm{ZrSiO}_{4}\right)$ (Fig. 9). In all probability, these are molten lumps of the clay lining the

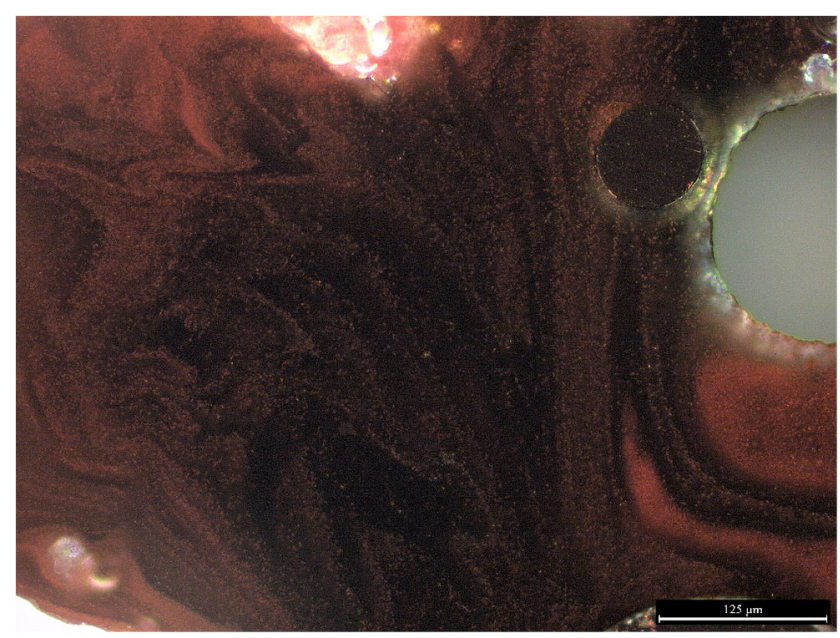

Fig. 8 OM micrograph of sample 11146-2 under reflected XPL light showing fine exsolution of cuprite within the slag. Note the metallic copper prill (black) next to a large round pore (top right). (Scale = $125 \mu \mathrm{m})$

reaction container, as also documented in other technical ceramic samples and in slag/ceramic interfaces (see below).

Sample $1215-5$ is broadly similar to the previous one, although it has an even clearer ceramic lump embedded within, and much lower $\mathrm{Fe}(1.6 \mathrm{wt} \% \mathrm{FeO})$ and higher $\mathrm{Cu}(8.8 \mathrm{wt} \%$ $\mathrm{CuO})$ levels. Correspondingly, the molten phase is dominated by fine cuprite globules, sometimes forming nodular or acicular arrangements that appear to grow around delafossite crystals that facilitate their nucleation (Fig. 10).

Overall, these small nodules are interpreted as indicative of the melting of unalloyed copper in a clay-lined pit or crucible. During melting, Fe potentially contained within the metal would be oxidised preferentially, hence refining the copper, but the formation of some cuprite would be practically

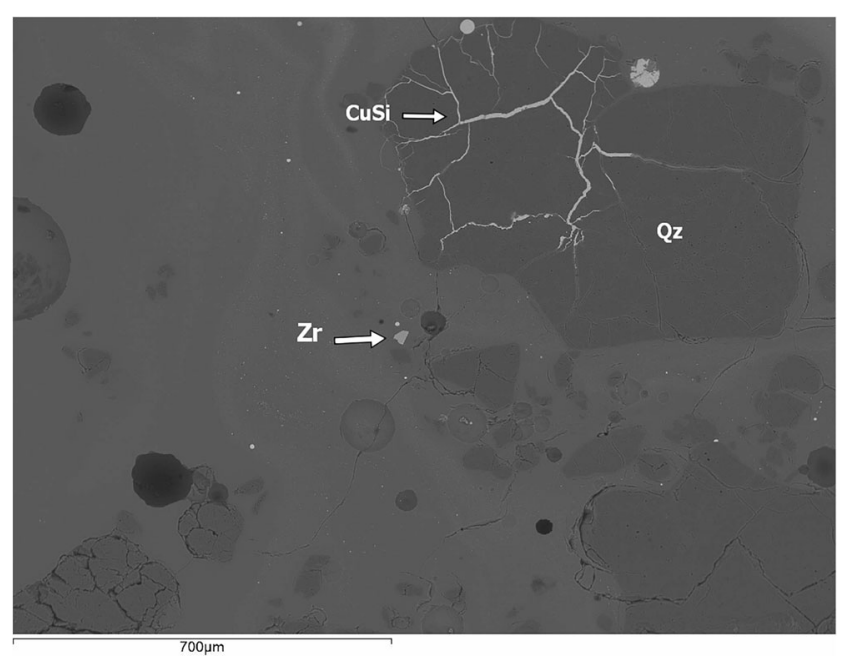

Fig. 9 BSE micrograph of sample 11146-2, showing abundant thermally distorted quartz $(\mathrm{Qz})$ and a small zircon $(\mathrm{Zr})$ inclusion in addition to small copper (cuprite?) globules. The bright $\mathrm{Cu}$-rich silicate phase filling the cracks of the larger quartz grain is likely post-depositional. (Scale $=700$ $\mu \mathrm{m})$ 


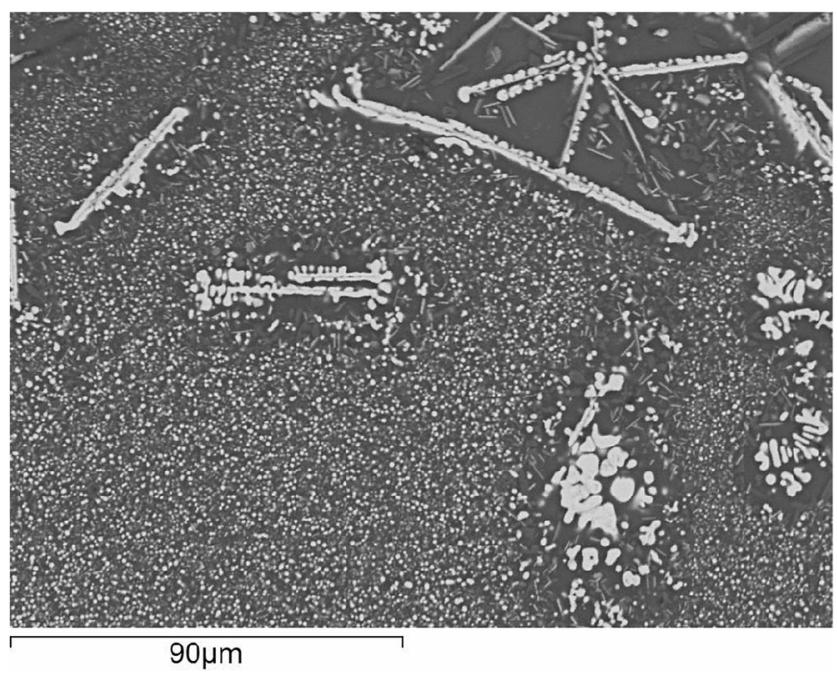

Fig. 10 BSE micrograph of sample 1215-5 showing its glassy matrix full of cuprite globules surrounding delafossite needles. $($ Scale $=90 \mu \mathrm{m})$

inevitable. The bulk of the samples is likely to constitute just molten clay, which would also explain the relatively higher $\mathrm{Al}$ levels of these samples. Conversely, compared with the copper smelting slag, these samples show no detectable presence of elements interpreted as ore impurities, such as $\mathrm{Zn}, \mathrm{Pb}$ or $\mathrm{Ba}$, corroborating their association to a later stage of the metallurgical chain.

\section{Bronze metallurgy}

Four slag samples (one of them attached to a thin ceramic layer) and a tuyère related to tin bronze metallurgy were sampled. Their analysis evinces the co-existence of the three intentional alloying methods as well as bronze recycling. Given the challenges associated with conclusively assigning a slag sample to a specific alloying method (Rademakers and Rehren 2016; Rademakers and Farci 2018) a combination of traits (summarised in Table 5) were characterised systematically. This section presents first the characterisation of the technical ceramics associated with bronze metallurgy, before focusing on the slag residues properly.

\section{Technical ceramics}

Two specimens with relatively undistorted ceramic remains were sampled. They have a 3-layer microstructure with a first horizontal layer of unaltered ceramic, a second layer of vitrified ceramic and a third slagged layer that would correspond to the area in contact with the charge.

Sample 1311-B4/5 is a tuyère of rounded section (Fig. 4, $4 \mathrm{~cm}$ inner diameter, $\sim 13 \mathrm{~cm}$ outer diameter, $\sim 4.5 \mathrm{~cm}$ wall thickness) externally covered by bronze corrosion products, which indicates contact with the charge. Its core preserves an intact very porous ceramic layer. Mineral inclusions (quartz and K-feldspar) of variable sizes together with elongated pores probably created by organic temper lost during fire could be observed. These inclusions improved the thermal shock resistance, increased its toughness, avoided the expansion of internal cracks, minimised the heat lost and enhanced its thermal stability (Freestone and Tite 1986; MartinónTorres and Rehren 2014). The size and uniform homogeneous distribution of the mineral inclusions within the clay matrix might be indicating conscious addition as temper. Zircon, different $\mathrm{Fe}$ oxide minerals and other silicates were common but too small to be considered intentionally added. Partly dissolved feldspars towards the ceramic surface indicate exposure to temperatures around $1050{ }^{\circ} \mathrm{C}$ at least, as this is the temperature at which feldspars start melting.

Sample 1311-B2 is a small fragment of pit lining fused to a thin black slagged layer. Green areas of bronze corrosion products can be identified on its surface. The ceramic contains numerous quartz inclusions and other silicate minerals, whose uniform size might indicate intentional addition. Small zircon and rare-earth phosphate minerals were also documented.

It is interesting to note that, if we allow for some chemical distortion through use, the composition of the ceramic matrices appears broadly similar (Table 6), but their inclusions are different. This would support intentional tempering as well as
Table 5 Slag characteristics that need to be considered when analysing tin bronze slag

\begin{tabular}{ll}
\hline Feature & Parameters observed \\
\hline Tin oxide crystals & $\cdot$ Presence/absence \\
& $\bullet$ Morphology \\
& $\bullet$ Composition (minor elements) \\
& $\bullet$ Distribution in relation to other slag phases \\
Ca-Sn or Ca-Sn-Si compounds & $\bullet$ Presence/absence \\
Metallic/oxidised droplets & Distribution in relation to other slag phases \\
Residual or semi-reacted minerals & $\bullet$ Composition (Sn amount and minor elements) \\
Composition of the slag and technical ceramics & $\bullet$ Presence/absence \\
\hline
\end{tabular}


Table 6 SEM-EDS mean compositions of the ceramic matrices of the technical ceramics

\begin{tabular}{lccccccccccc}
\hline $\mathrm{ID}$ & $\mathrm{Na}_{2} \mathrm{O}$ & $\mathrm{MgO}$ & $\mathrm{Al}_{2} \mathrm{O}_{3}$ & $\mathrm{SiO}_{2}$ & $\mathrm{P}_{2} \mathrm{O}_{5}$ & $\mathrm{~K}_{2} \mathrm{O}$ & $\mathrm{CaO}$ & $\mathrm{TiO}_{2}$ & $\mathrm{MnO}$ & $\mathrm{FeO}$ & $\begin{array}{l}\text { Anal. } \\
\text { total }\end{array}$ \\
\hline $1311-\mathrm{B} 2$ & 2.8 & 1.7 & 21.4 & 58.5 & 0.5 & 4.3 & 6.7 & 0.7 & $\mathrm{ND}$ & 3.4 & 99.8 \\
$1311-\mathrm{B} 4 / 5$ & 1.8 & 2.7 & 24.8 & 54.0 & 0.4 & 4.0 & 2.3 & 1.5 & 0.9 & 8.3 & 90.2 \\
\hline
\end{tabular}

$N D$ not detected

raising the possibility of some form of functional specialisation - an issue to be investigated when more samples become available.

In any event, it is also useful to compare the composition of the technical ceramics to that of the associated slagged layers, for an indication of which slag oxides simply derived from melted ceramic, as opposed to those contributed by the metallurgical charge. For this purpose, we can use these two slagged ceramic samples but also sample 11109-1, which is a bronze slag with three distinct layers, one of which appears to constitute mostly vitrified ceramic, although no unreacted ceramic was preserved. From this comparison (Table 7), it is apparent that the concentrations of $\mathrm{Na}_{2} \mathrm{O}, \mathrm{Al}_{2} \mathrm{O}_{3}, \mathrm{SiO}_{2}, \mathrm{~K}_{2} \mathrm{O}$ and $\mathrm{TiO}_{2}$ are higher in the ceramic (as well as $\mathrm{Cl}$, most likely owing to post-depositional alteration; see Freestone 2001). Conversely, the slagged layers are richer in $\mathrm{MgO}, \mathrm{P}_{2} \mathrm{O}_{5}$, $\mathrm{CaO}$ and $\mathrm{MnO}$, in addition to the heavy metal oxides. The enrichment in all four oxides may be related to contributions from charcoal ash, although it is possible that at least some input may also derive from gangue associated with the minerals processed. The levels of $\mathrm{FeO}$ are not particularly enriched in the slag, bar for some exceptions to be discussed below (sample 11109-1).

\section{Bronze slag}

The glassy matrix of the external slagged layer attached to tuyère $1311-\mathrm{B} 4 / 5$ is rich in $\mathrm{Cu}$ oxide (11.1 wt\%). This enrichment is interpreted by Rovira (2007) as indicative of the former presence of copper minerals (as opposed to metal) in the charge, which would be more reactive to form silicates. The presence of subrounded clusters of CuO-rich microcrystals, perhaps pseudomorphs of partly reacted copper-bearing ores, would seem to support this inference (Fig. 11; Table 8). No metallic droplets were found.

In a similar vein, the slagged layer also contains clusters of semi-dissolved cassiterite (Fig. 12), which relates this tuyère to an alloying process where $\mathrm{Sn}$ was added in mineral form (either co-smelting or cementation). Even though $\mathrm{Sn}$ oxide may have been absorbed by tuyère slag from the $\mathrm{Sn}$ vapours produced during the operation (Rademakers and Farci 2018), it is worth noting that no $\mathrm{Sn}$ was detected in the slag matrix composition (Table 8). While $\mathrm{SnO}$ can dissolve in a silicate glass, $\mathrm{SnO}_{2}$ (as found in mineral cassiterite) does not react with silica under high temperatures (Kearns et al. 2010). Hence, the absence of $\mathrm{Sn}$ in the slag matrix supports the proposition that this element entered the system as mineral $\mathrm{SnO}_{2}$, and it was never reduced - at least, in the area of the sample analysed. The locally oxidising conditions in this region would have prevented the reduction of metallic Sn, while some $\mathrm{Cu}$ oxides may have remained unreduced too. Overall, we are inclined to interpret this sample as associated with a cosmelting reaction, although the cementation of mineral $\mathrm{Sn}$ with metallic copper cannot be ruled out.

The glassy matrix of the slagged layer attached to ceramic in sample 1311-B2 is formed by a Ca-Al silicate with a considerable amount of $\mathrm{Cu}$ oxide $(8.6 \mathrm{wt} \%)$ and a remarkable

Table 7 SEM-EDS mean bulk compositions of the different layers of the technical ceramics including sample 11109-1. Note that the analytical totals are low for the unaltered ceramic areas because of its porosity

\begin{tabular}{|c|c|c|c|c|c|c|c|c|c|c|c|c|c|c|c|c|}
\hline ID & Location & $\mathrm{Na}_{2} \mathrm{O}$ & $\mathrm{MgO}$ & $\mathrm{Al}_{2} \mathrm{O}_{3}$ & $\mathrm{SiO}_{2}$ & $\mathrm{P}_{2} \mathrm{O}_{5}$ & $\mathrm{Cl}$ & $\mathrm{K}_{2} \mathrm{O}$ & $\mathrm{CaO}$ & $\mathrm{TiO}_{2}$ & $\mathrm{MnO}$ & $\mathrm{FeO}$ & $\mathrm{CuO}$ & $\mathrm{SnO}_{2}$ & $\mathrm{PbO}$ & Anal. total \\
\hline 1311-B4/5 & Unaltered ceramic & 1.6 & 1.2 & 14.8 & 70.8 & ND & 0.2 & 4.2 & 2.1 & 0.6 & 0.7 & 4.1 & ND & ND & ND & 66.7 \\
\hline 1311-B4/5 & Vitrified ceramic & 1.5 & 1.4 & 14.4 & 70.1 & ND & ND & 3.5 & 2.7 & 0.6 & ND & 5.1 & 0.9 & ND & ND & 71.8 \\
\hline $1311-B 4 / 5$ & Slagged layer & 1.7 & 1.6 & 13.3 & 65.4 & 0.5 & ND & 4.4 & 3.7 & 0.6 & 0.3 & 4.4 & 4.4 & ND & ND & 76.1 \\
\hline 1311-B2 & Unaltered ceramic & 1.8 & 1.3 & 13.2 & 70.1 & ND & 0.3 & 3.0 & 4.2 & 0.6 & ND & 4.9 & 0.4 & ND & ND & 52.7 \\
\hline 1311-B2 & Vitrified ceramic & 2.4 & 1.3 & 13.7 & 67.3 & ND & ND & 3.6 & 5.7 & 0.6 & 0.2 & 3.7 & 1.3 & ND & ND & 80.0 \\
\hline 1311-B2 & Slagged layer & ND & 2.6 & 7.7 & 40.5 & 1.0 & ND & ND & 7.8 & ND & 0.6 & 2.1 & 13.0 & 19.7 & 0.6 & 97.2 \\
\hline $11109-1$ & Vitrified ceramic & 2.4 & 1.0 & 15.3 & 69.9 & ND & ND & 5.7 & 2.2 & 0.7 & ND & 2.9 & ND & ND & ND & 97.1 \\
\hline $11109-1$ & Slagged layer 1 (interm.) & 3.5 & 4.0 & 11.3 & 53.8 & 1.0 & ND & 2.2 & 13.5 & 0.6 & 1.4 & 8.2 & 0.4 & ND & ND & 94.2 \\
\hline $11109-1$ & Slagged layer 2 (inner) & 3.0 & 3.7 & 9.3 & 47.4 & 1.1 & ND & 1.5 & 13.6 & 0.6 & 1.6 & 17.4 & 0.8 & ND & ND & 91.1 \\
\hline
\end{tabular}

$N D$ not detected 


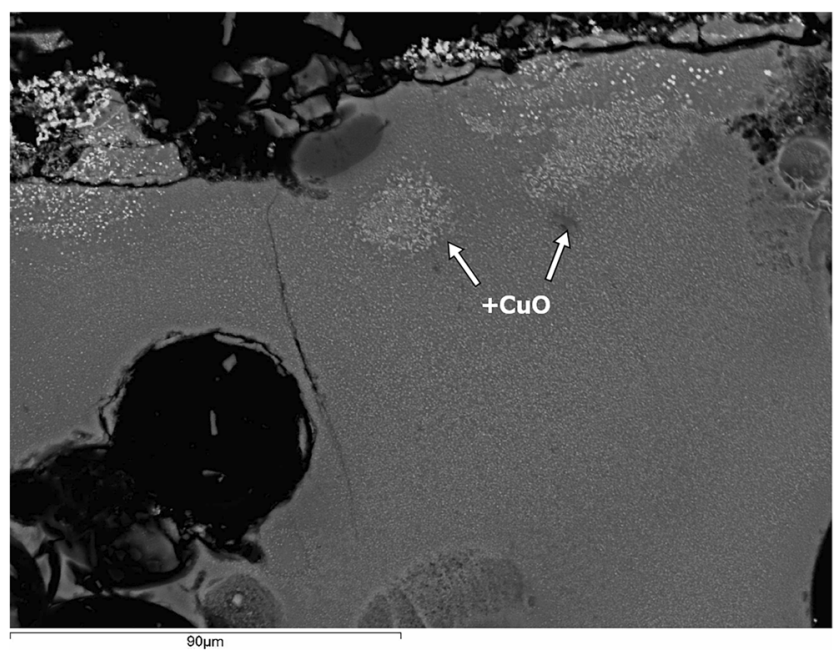

Fig. 11 BSE micrograph of sample 1311-B4/5. Note the $\mathrm{CuO}$ concentrations $(+\mathrm{CuO})$ of rounded shape in the upper slagged layer. $($ Scale $=90 \mu \mathrm{m})$

presence of $\mathrm{PbO}(1.0 \mathrm{wt} \%)$ but no $\mathrm{Sn}$ oxide dissolved in it (Table 9). When compared the bulk compositions of the ceramic layers, there is no $\mathrm{Fe}$ oxide enrichment in the slag (Table 7 and discussion below). Several $\mathrm{Cu}$ droplets with minor Fe impurities were analysed, but only two within this group had detectable $\mathrm{Sn}$ amounts (7.6 wt $\% \mathrm{Sn}$ and $1.7 \mathrm{wt} \% \mathrm{Sn}$ respectively). However, crystalline $\mathrm{Sn}$ oxide was recognised both as euhedral needles (usually with a metallic $\mathrm{Cu}$ core) and as likely pseudomorphs or natural minerals dispersed through all the slag (Fig. 13). Both the Cu-cored rhombohedral crystals and the euhedral needles are typical of metallic bronze reoxidation, and they result from the higher oxygen affinity of Sn compared with $\mathrm{Cu}$ (Rovira 2007; Dungworth 2000). As a matter of fact, some of the metal droplets are surrounded by concentric arrangements of Sn oxide crystals that might be indicating the progressive re-oxidation of the metallic $\mathrm{Sn}$ from an original bronze droplet (Fig. 13). However, as recently emphasised by Rademakers and Farci (2018), crystal habit alone cannot be taken as diagnostic of a specific alloying method, not least as the bronze oxidation could have followed a reduction stage within the same vessel. In fact, some parts of the sample display nodular clusters of subhedral Sn oxide crystals that might constitute pseudomorphs of partially dissolved cassiterite (Fig. 14) (Rademakers et al. 2018).

This last piece of evidence raises the possibility of cassiterite addition during the melting of bronze - a relatively

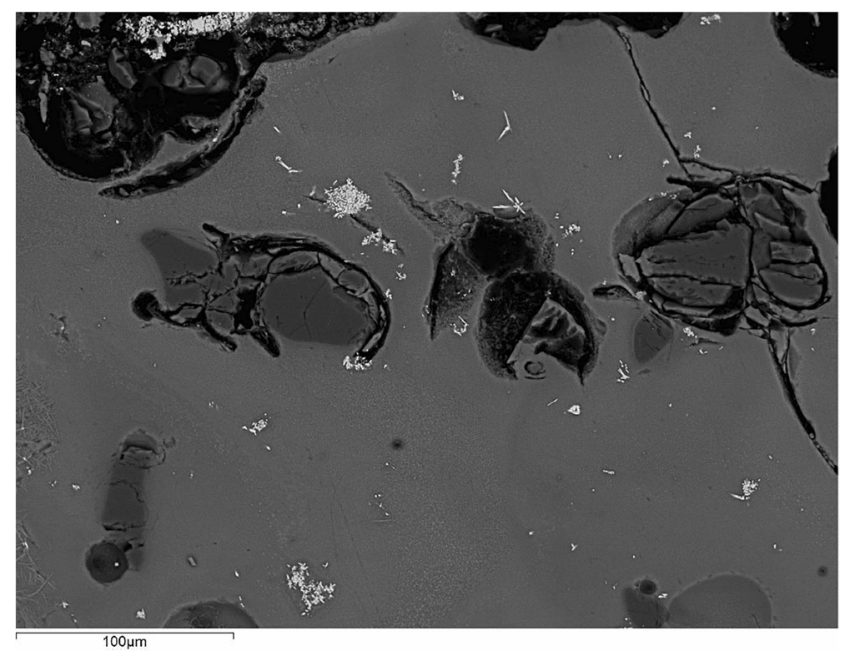

Fig. 12 BSE micrograph of sample 1311-B4/5. Note the white cassiterite clusters in the slagged upper layer. (Scale $=100 \mu \mathrm{m})$

common technique in IA-I (Rovira Lloréns 2000; Rovira et al. 2003). This $\mathrm{SnO}_{2}$ addition would have aimed at balancing the loss of $\mathrm{Sn}$ that can be expected during melting. $\mathrm{Pb}$ is more volatile than $\mathrm{Cu}$ and $\mathrm{Sn}$, and therefore, under oxidising conditions, it would be easier for it to react with the vitrified slagged layer (Dungworth 2000; Kearns et al. 2010). The low amounts recorded in the slag likely reflect its former presence as an impurity in the charge, rather than the use of leaded alloys. Overall, it is thus possible that this slag represents the 're-alloying' of bronze with additional cassiterite (hence falling under the 're-melting' category in Table 1), although the hypothesis of a simple cementation process, followed by partial re-oxidation of the resulting bronze, is plausible too.

$N D$ not detected

Three small bronze slag lumps were sampled. Like the slag layers adhering to technical ceramics, their glassy matrices are enriched in ceramic oxides as well as $\mathrm{MgO}, \mathrm{P}_{2} \mathrm{O}_{5}, \mathrm{CaO}$ and $\mathrm{MnO}$, which is suggestive of similar choices of ceramics and charcoal (Table 9). The levels of Fe oxide are more variable between samples but generally low, which explains why none of these slags is fayalitic. Also variable are the concentrations of $\mathrm{Sn}$ and $\mathrm{Cu}$ oxides, which may be related to the nature and efficiency of each operation. $\mathrm{Pb}$ oxide is only detected occasionally.

Table 8 SEM-EDS mean compositions of the glassy matrix of sample 1311-B4/5 and the CuO-enriched areas

\begin{tabular}{lccccccccccccc}
\hline & $\mathrm{Na}_{2} \mathrm{O}$ & $\mathrm{MgO}$ & $\mathrm{Al}_{2} \mathrm{O}_{3}$ & $\mathrm{SiO}_{2}$ & $\mathrm{P}_{2} \mathrm{O}_{5}$ & $\mathrm{~K}_{2} \mathrm{O}$ & $\mathrm{CaO}$ & $\mathrm{TiO}_{2}$ & $\mathrm{MnO}$ & $\mathrm{FeO}$ & $\mathrm{CuO}$ & $\mathrm{SnO}$ & $\mathrm{Anal}$. total \\
\hline Glassy matrix & 1.9 & 2.4 & 11.6 & 54.7 & 0.9 & 6.3 & 5.5 & 0.6 & 0.8 & 4.0 & 11.1 & $\mathrm{ND}$ & 93.8 \\
$\mathrm{CuO}$-rich area 1 & 2.0 & 1.6 & 8.1 & 50.9 & 1.3 & 7.0 & 3.3 & 0.5 & 1.1 & 2.7 & 21.4 & $\mathrm{ND}$ & 95.3 \\
$\mathrm{CuO}$-rich area 2 & 2.0 & 1.6 & 8.9 & 50.7 & 1.5 & 7.4 & 3.3 & 0.4 & 1.3 & 3.7 & 19.1 & $\mathrm{ND}$ & 95.6 \\
\hline
\end{tabular}

ND not detected 
Table 9 SEM-EDS mean bulk and glassy matrices compositions of bronze slags including the inner slagged layers (i.e. furthest away from ceramic) of sample 1311-B4/5, 1311B2 and 11109-1

\begin{tabular}{|c|c|c|c|c|c|c|c|c|c|c|c|c|c|c|c|}
\hline ID & & $\mathrm{Na}_{2} \mathrm{O}$ & $\mathrm{MgO}$ & $\mathrm{Al}_{2} \mathrm{O}_{3}$ & $\mathrm{SiO}_{2}$ & $\mathrm{P}_{2} \mathrm{O}_{5}$ & $\mathrm{~K}_{2} \mathrm{O}$ & $\mathrm{CaO}$ & $\mathrm{TiO}_{2}$ & $\mathrm{MnO}$ & $\mathrm{FeO}$ & $\mathrm{CuO}$ & $\mathrm{SnO}_{2}$ & $\mathrm{PbO}$ & Anal. total \\
\hline $1311-B 4 / 5$ & Bulk (slagged layer) & 1.7 & 1.6 & 13.3 & 65.4 & 0.5 & 4.4 & 3.7 & 0.6 & 0.3 & 4.4 & 4.4 & ND & ND & 76.1 \\
\hline 1311-B2 & Bulk (slagged layer) & ND & 2.6 & 7.7 & 40.5 & 1.0 & ND & 7.8 & ND & 0.6 & 2.1 & 16.0 & 19.7 & 0.6 & 97.2 \\
\hline $11109-1$ & Bulk (slagged layer 2) & 3.0 & 3.7 & 9.3 & 47.4 & 1.1 & 1.5 & 13.6 & 0.6 & 1.6 & 17.4 & 0.8 & ND & ND & 91.1 \\
\hline 1311-A2 & Bulk & ND & 1.1 & 5.7 & 46.5 & 0.4 & 1.6 & 7.3 & 0.4 & 0.5 & 2.8 & 21.9 & 15.4 & ND & 99.7 \\
\hline $1171-4$ & Bulk & ND & 2.0 & 4.6 & 25.1 & 1.6 & ND & 7.6 & ND & 0.5 & 2.1 & 19.0 & 37.5 & ND & 99.6 \\
\hline $1311-B 4 / 5$ & Glassy matrix (slagged layer) & 1.9 & 2.4 & 11.6 & 54.7 & 0.9 & 6.3 & 5.5 & 0.6 & 0.8 & 4.0 & 11.1 & ND & ND & 93.8 \\
\hline 1311-B2 & Glassy matrix (slagged layer) & 3.7 & 3.7 & 9.8 & 49.3 & 1.5 & 3.7 & 13.4 & 0.5 & 1.1 & 3.6 & 8.6 & ND & 1.0 & 96.0 \\
\hline $11109-1$ & Glassy matrix (slagged layer 2) & 2.8 & 3.8 & 9.3 & 47.4 & 1.0 & 1.4 & 13.6 & 0.6 & 1.6 & 18.4 & ND & ND & ND & 95.9 \\
\hline 1311-A2 & Glassy matrix & 1.5 & 1.7 & 9.3 & 49.5 & 0.7 & 2.3 & 8.2 & 0.4 & 0.8 & 4.5 & 17.3 & 15.4 & ND & 97.7 \\
\hline $1171-4$ & Glassy matrix & 1.7 & 3.0 & 8.8 & 50.8 & 4.3 & 3.3 & 17.4 & 0.4 & 0.9 & 3.3 & 6.3 & 6.6 & ND & 94.1 \\
\hline
\end{tabular}

$N D$ not detected

Sample 1311-A2 represents a co-smelting reaction. Its silicate glassy matrix displays the greatest losses of $\mathrm{CuO}$ and $\mathrm{SnO}_{2}$ among all samples (Table 9) - as typical of this method (Rovira 2007). In the Cu-based droplets found within the matrix, the amounts of $\mathrm{Sn}$ are highly variable, from below detection limits up to $50 \mathrm{wt} \% \mathrm{Sn}$ ( $\varepsilon$-phase). This variability, and particularly the presence of high Sn bronze prills, leads us to rule out refining or recycling because no bronzes with such high Sn levels are known for artefacts in the IA-I: clearly, Sn entered the system separately, either as a metal or, more likely, as an oxide (see below). Some of the $\mathrm{Cu}$ droplets are partially re-oxidised, as shown by the cuprite dendrites surrounding them. These features reflect the variable redox conditions during the operation. Although many of the $\mathrm{Cu}$ droplets are corroded, it is possible to confirm the recurrent presence of $\mathrm{Fe}$ and As as minor impurities, which might be related to the original $\mathrm{Cu}$ ore used.

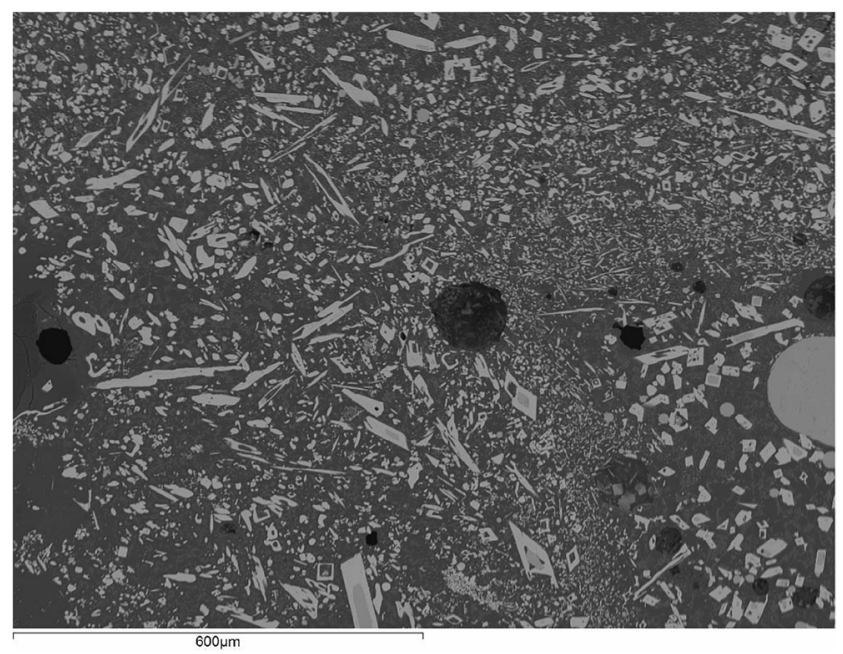

Fig. 13 BSE micrograph of sample 1311-B2. Note the slag matrix full of tin oxide crystals and the concentric arrangement surrounding the copper droplet located on the right side of the picture
Figure 15 shows a region of the slag dominated by subcircular areas with cores very rich in $\mathrm{Cu}$ oxides that may constitute relics of the unreduced $\mathrm{Cu}$ ore grains. Under higher magnification, diagnostic evidence of the reduction of $\mathrm{Cu}$ ores can be identified: this takes the form of subspherical globules made of a cuprite skin surrounding a core of cuprite worms (Fig. 16). Clearly, these are the result of the partial solid-state reduction of a more oxidised $\mathrm{Cu}$ mineral, probably malachite, in each ore grain: as hydroxides and carbonates were removed by evaporation from the outside in, the $\mathrm{Cu}$-bearing crystals become smaller but retain their original arrangement. These $\mathrm{Cu}$-rich areas are surrounded by $\mathrm{Sn}$ oxide crystals of diverse morphology: euhedral and elongated needles and pseudomorphic clusters. The latter suggests the addition of cassiterite to

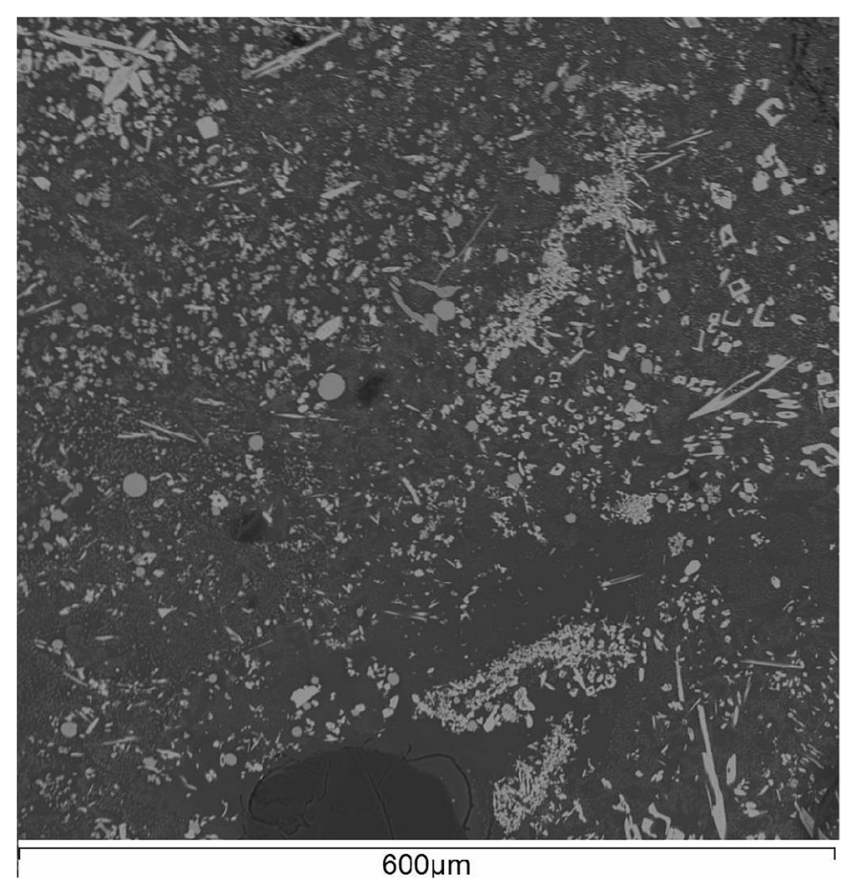

Fig. 14 BSE micrograph of sample 1311-B2. Note tin oxide clusters 


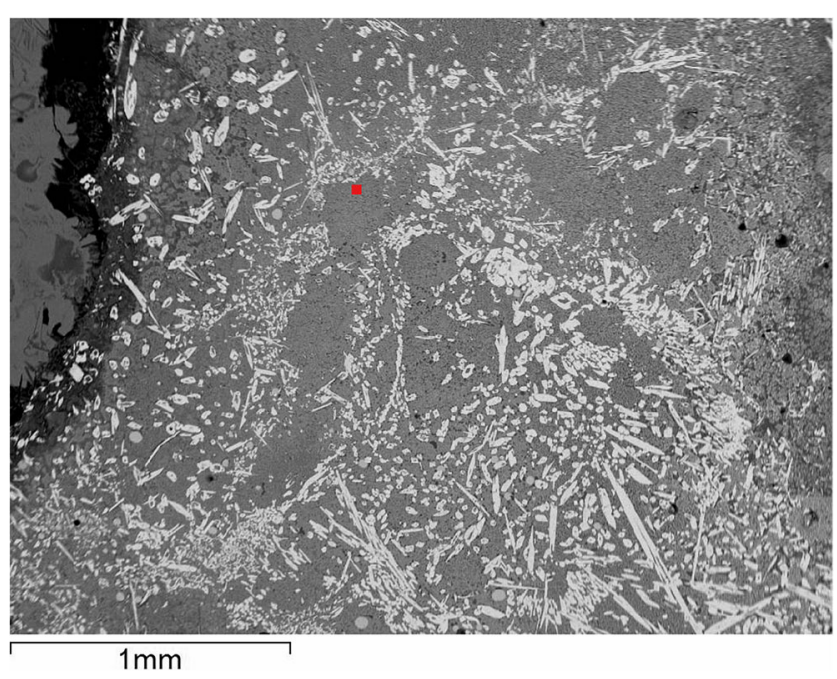

Fig. 15 BSE micrograph of sample 1311-A2. Note the Sn oxide crystals (white) surrounding grey oval areas rich in $\mathrm{CuO}$. Sn oxide clusters can be appreciated. The red square indicates the area zoomed in Fig. 16

the original charge. Of particular significance is not only the presence of elongated Sn oxide needles (commonly found in naturally occurring cassiterite; cf. Rovira 2007) but also the detection of tantalum in these crystals. This element is commonly associated with mineral cassiterite but would not be reduced to metal; as such, its presence is a strong indication that $\mathrm{Sn}$ oxide was added to the charge in mineral form (Farci et al. 2017; Rademakers and Farci 2018). This feature confirms that both $\mathrm{Cu}$ and $\mathrm{Sn}$ entered the reaction as minerals, but also the variable, perhaps insufficient, temperature and redox environment.

Turning to slag sample 1171-4, this could be an example of a co-smelting or cementation. The glassy matrix is enriched in both $\mathrm{CuO}$ and $\mathrm{SnO}_{2}$, but not as highly as the previous sample.



Fig. 16 BSE micrograph of sample 1311-A2 that shows a closer view of one of the oval areas observed on Fig. 15. Note the cuprite formations resulting from the reduction of $\mathrm{Cu}$ ores, interspersed with $\mathrm{Sn}$ oxide crystals (white)
The composition of the numerous droplets of metal trapped within varies, from nominally pure $\mathrm{Cu}$ with minor $\mathrm{Fe}$ impurities to $\mathrm{Sn}$ bronze with $48 \mathrm{wt} \% \mathrm{Sn}$ ( $\varepsilon$-phase). Only in two prills were minor $\mathrm{S}$ and $\mathrm{Sb}$ detected, probably $\mathrm{Cu}$ ore impurities, and a few of them showed traces of chlorine that most likely results from corrosion. Like before, the presence of bronze globules with such high Sn content is clearly indicative of active alloying with $\mathrm{Sn}$.

Sn oxides were found in this sample as euhedral and elongated needles and pseudomorphs that might be interpreted as undissolved Sn ores (Rademakers et al. 2018), while admitting that this feature alone is not conclusive evidence (Rademakers and Farci 2018). The presence of newly formed $\mathrm{Ca}-\mathrm{Sn}$ and $\mathrm{Ca}-\mathrm{Sn}-\mathrm{Si}$ compounds surrounding $\mathrm{Sn}$ oxide crystals also indicates that $\mathrm{Sn}$ entered the system as mineral (Renzi 2013). No conclusive evidence was found to verify how copper entered the system; although cuprite crystals were observed, they occurred in some of the internal pores and as such they may be the result of the solidification processes or postdepositional re-oxidation (Farci et al. 2017). Other pore infills, predominantly rich in $\mathrm{Si}$ and $\mathrm{Sn}$ oxide and most likely postdepositional, were observed in this sample.

The last sample is of particular interest as it appears to present evidence of a different alloying process-namely, the mixture of metallic copper and tin. Slag sample 11109-1 has a layered microstructure with a vitrified ceramic layer rich in quartz inclusions, a first intermediate slagged layer and a second slagged layer that would have been the one in contact with the charge (Table 7). The slag glassy matrix is a $\mathrm{Ca}-\mathrm{Al}$ silicate that clearly becomes more enriched in Fe oxide as we move away from the ceramic (Table 7). Interestingly, no $\mathrm{CuO}$ or $\mathrm{SnO}_{2}$ was detected in the glassy matrix (Table 9): all the

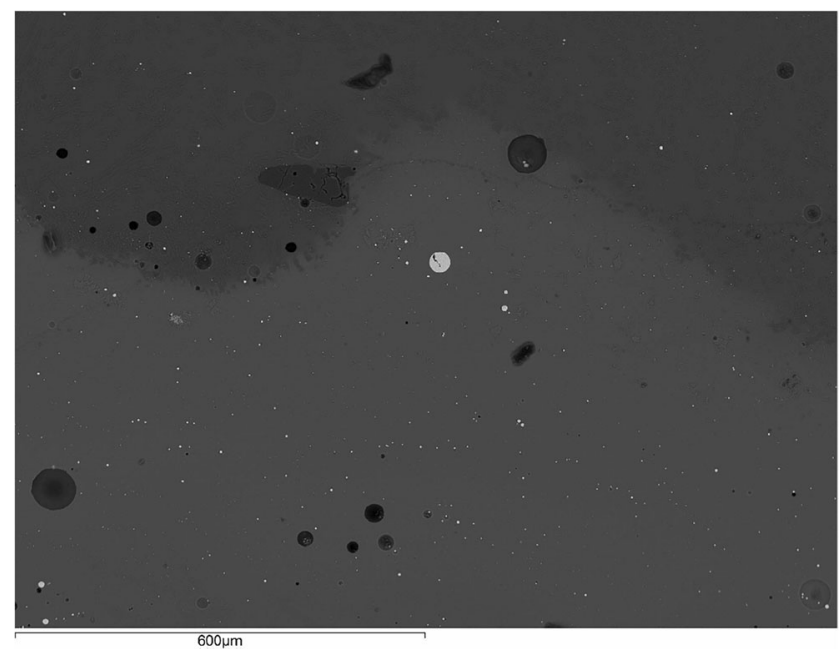

Fig. 17 General view of the upper slag layer of sample 11109-1. Note the darker line that separates the inner slagged layer (down) and the intermediate slagged later (top) as well as the absence of Sn oxide crystals. (Scale $=600 \mu \mathrm{m})$ 


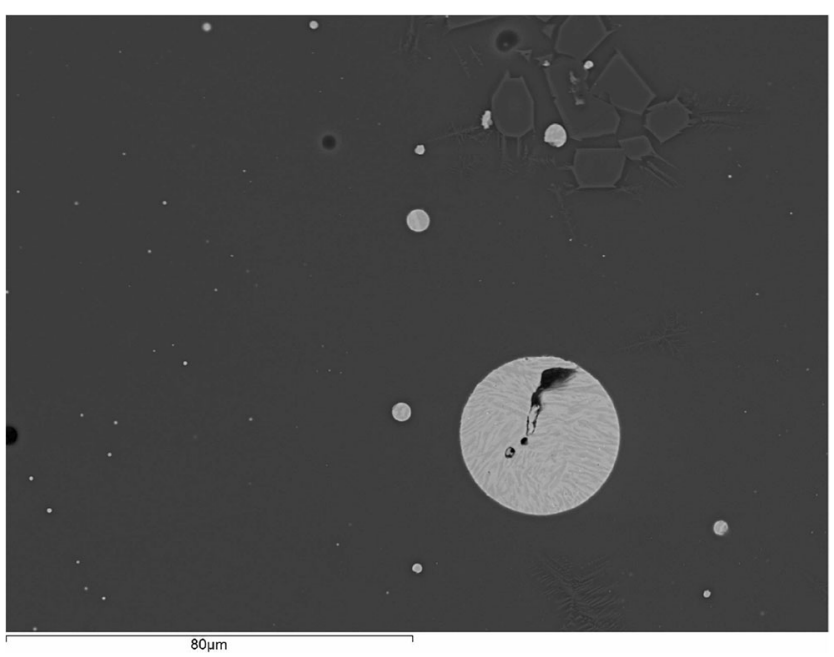

Fig. 18 Closer view into the innermost slagged layer of sample 11109-1. Note the high Sn content of the bronze prills (visible $\alpha+\delta$ interdendritic) and the rare $\mathrm{Mg}$ - and $\mathrm{Fe}$-dominated olivine crystals (top right). (Scale = $80 \mu \mathrm{m})$

$\mathrm{Cu}$ - and Sn-bearing phases are found in the metallic state (Fig. 17).

Metallic droplets are quite numerous and mostly trapped in the innermost layer (i.e. furthest away from the ceramic). All of them are $\mathrm{Sn}$ bronzes with compositions clustering relatively tightly between 16 and $24 \mathrm{wt} \%$ Sn ( $\delta$-phase and $\alpha+\delta$ interdendritic) and with detectable Fe in all cases. The only oxide crystals suspended in this slag layer are very occasional $\mathrm{Mg}$ - and Fe-dominated olivines (Fig. 18).

Bronzes with Sn contents reaching $24 \%$ are extraordinarily uncommon in the metallurgical panorama of IA-I, which supports the inference of active alloying as the reaction taking place here. Furthermore, the conspicuous absence of Sn or $\mathrm{Cu}$ oxide in the oxide phases is a strong indication that both elements entered the system in metal form. Thus, the addition of metallic Sn to copper seems the most plausible explanation. Although all the metal alloying experiments conducted by Rademakers and Farci (2018) resulted in the formation of Sn oxide crystals, the good control of stable reducing conditions in this case would have avoided the formation of these phases. The minor Fe enrichment in the slag could derive from the slight oxidation of the ferruginous copper, whereas all the other oxides in the slag may be attributed to either ceramic or charcoal ash contributions.

The re-oxidation of $\mathrm{Fe}$ and the metallic state of $\mathrm{Sn}$ allow an estimate of the redox parameters. Assuming working temperatures between 800 and $1000{ }^{\circ} \mathrm{C}$ (allowing for the lower melting point of high $\mathrm{Sn}$ bronze) the $\mathrm{pO}_{2}$ would have been maintained between $\sim 10^{-15}-10^{-22}$ during all the operation, at least in this area.

Table 10 shows the composition of different metallic droplets analysed in every bronze slag. Only the droplets in sample 11109-1, presumably obtained by co-melting, have a composition $\sim 19 \mathrm{wt} \%$ Sn while other samples have considerable variability in the amounts of $\mathrm{Sn}$ in their metallic prills. This is consistent with the proposition that the co-melting of metals allows better control of the alloy produced, creating a more homogeneous and predictable proportion of Sn in copper. While it is generally dangerous to estimate the alloy composition based on the analysis of slag prills, these are more likely to be representative of the original product when the operation occurred under reducing conditions, as is the case here (Dungworth 2000; Rademakers and Rehren 2016). Significantly, the mean composition of the droplets in sample 11109-1 is consistent with the compositional trends for representative coeval bronze objects of different typologies and functionalities from Catalonia (13.5 $\pm 5.9 \mathrm{wt} \% \mathrm{Sn})$ described by Rovira Llorens (2000).

\section{Discussion and conclusions}

The interpretation of the archaeological structures, together with macroscopic and microscopic observations and chemical analyses of metallurgical debris, has shown that metallurgists at Emporion carried out copper smelting and melting, bronze recycling and bronze alloying using different techniques, in addition to iron smelting and forging (results for iron not shown here).

Copper extractive technology at Emporion can be considered simple, inefficient and 'primitive', as typical of prehistoric Iberia, given the use of simple pits with a clay lining, resulting in considerable metal losses in the slag. The smelting slags (samples 1215-4 and 1171-2) point to the use of an oxidic $\mathrm{Cu}$ ore rich in Fe oxide; this might indicate the exploitation of local sources, given that the majority of the upper $\mathrm{Cu}$ ore deposits of the north-eastern area are formed by the oxidation of chalcopyrite $\left(\mathrm{CuFeS}_{2}\right.$ ) (Soriano 2013). $\mathrm{BaO}, \mathrm{ZnO}$ and $\mathrm{PbO}$ were found to be the characteristic impurities of this ore, although their occurrence is variable. The occasional presence of low amounts of $\mathrm{Sn}$ and $\mathrm{Sb}$ might support the use of local ores, as previous studies at mines such as La Ferrera and Manera have documented polymetallic $\mathrm{Cu}-\mathrm{Sn}$ minerals with Sb impurities (Alcalde et al. 1998).

Although the presence of $\mathrm{Fe}$ in metallic copper has been related to highly reducing slagging smelting (Craddock and Meeks 1987), in this case, the variable behaviour of both elements and the variable levels of $\mathrm{Fe}$ in $\mathrm{Cu} / \mathrm{Cu}_{2} \mathrm{O}$ droplets trapped in the slag (up to $3.8 \mathrm{wt} \% \mathrm{Fe}$ ) seem more likely to derive from unstable reducing conditions and are common for the working installations and technology described. The operation occurred in a non-equilibrium system that produced a viscous slag with relatively poor control of the working parameters.

The copper melting slags (samples 11146-2 and 1215-5) also showed considerable amounts of $\mathrm{Fe}$ as an impurity in 
Table 10 SEM-EDS composition of bronze prills in bronze slags. Only unoxidised prills are included

\begin{tabular}{|c|c|c|c|c|c|c|c|c|c|c|c|c|}
\hline Sample & ID & $\mathrm{O}$ & $\mathrm{Mg}$ & Al & $\mathrm{Si}$ & $\mathrm{Ca}$ & $\mathrm{Mn}$ & $\mathrm{Fe}$ & $\mathrm{Cu}$ & $\mathrm{Sr}$ & Sn & Anal. total \\
\hline 1311;B2 & Prill 1 & 1.03 & ND & ND & ND & ND & ND & 0.20 & 98.23 & 0.54 & ND & 95.01 \\
\hline 1311;B2 & Prill 2 & 1.13 & ND & ND & 0.09 & 0.13 & ND & 0.22 & 97.86 & 0.56 & ND & 94.55 \\
\hline 1311;B2 & Prill 3 & 0.69 & ND & ND & ND & 0.11 & ND & 0.25 & 98.36 & 0.60 & ND & 93.67 \\
\hline 1311;B2 & Prill 4 & 0.65 & ND & ND & ND & ND & ND & ND & 98.78 & 0.56 & ND & 95.50 \\
\hline 1311;B2 & Prill 5 & 1.12 & ND & ND & 0.15 & ND & ND & 0.48 & 90.25 & 0.36 & 7.63 & 99.75 \\
\hline 1311;A2 & Metallic area & 1.01 & ND & ND & ND & 0.14 & ND & ND & 98.85 & ND & $\mathrm{ND}$ & 96.35 \\
\hline 1311;A2 & Prill 1 & 0.67 & ND & ND & ND & ND & ND & ND & 99.33 & ND & ND & 95.73 \\
\hline $1311 ; \mathrm{A} 2$ & Prill 2 & 0.87 & ND & ND & ND & ND & ND & 0.32 & 98.82 & ND & ND & 96.16 \\
\hline 1311;A2 & Prill 3 & 0.52 & ND & ND & ND & ND & ND & 0.28 & 99.20 & ND & ND & 96.25 \\
\hline 1311;A2 & Prill 4 & 0.63 & ND & ND & ND & ND & ND & ND & 99.37 & ND & $\mathrm{ND}$ & 96.79 \\
\hline 1311;A2 & Prill 5 & 0.92 & ND & ND & ND & ND & $\mathrm{ND}$ & 0.20 & 90.76 & ND & 8.12 & 97.76 \\
\hline 1311;A2 & Prill 6 & 0.96 & ND & ND & ND & ND & ND & ND & 83.69 & ND & 15.35 & 97.90 \\
\hline 1311;A2 & Prill 7 & 1.54 & ND & ND & ND & ND & ND & ND & 55.59 & ND & 42.88 & 99.51 \\
\hline 1311;A2 & Prill 8 & 1.43 & ND & ND & ND & ND & ND & ND & 48.72 & ND & 49.84 & 98.97 \\
\hline $1171 ; 4$ & Metallic area & 1.66 & ND & ND & ND & ND & ND & ND & 98.34 & ND & $\mathrm{ND}$ & 99.70 \\
\hline $1171 ; 4$ & Prill 1 & 0.55 & ND & ND & ND & ND & ND & 0.20 & 99.25 & ND & $\mathrm{ND}$ & 102.16 \\
\hline $1171 ; 4$ & Prill 2 & 2.33 & ND & 0.24 & 1.04 & 0.71 & ND & 0.35 & 85.84 & ND & 9.49 & 97.08 \\
\hline $1171 ; 4$ & Prill 3 & 2.33 & ND & ND & ND & ND & ND & 0.27 & 89.23 & ND & 9.66 & 99.63 \\
\hline $1171 ; 4$ & Prill 4 & 0.84 & ND & ND & ND & ND & ND & ND & 61.47 & ND & 38.53 & 99.19 \\
\hline $1171 ; 4$ & Prill 5 & ND & ND & ND & 0.40 & ND & ND & ND & 56.56 & ND & 43.04 & 98.14 \\
\hline $1171 ; 4$ & Prill 6 & ND & ND & ND & ND & ND & ND & ND & 51.54 & ND & 48.46 & 100.58 \\
\hline 11109 & Prill 1 & 2.17 & ND & ND & 0.30 & 0.25 & ND & 2.52 & 79.25 & ND & 15.50 & 103.25 \\
\hline 11109 & Prill 2 & 4.20 & 0.33 & 0.38 & 1.41 & 0.52 & ND & 2.90 & 74.00 & ND & 16.27 & 108.00 \\
\hline 11109 & Prill 3 & 2.30 & ND & ND & 0.29 & ND & ND & 0.56 & 77.35 & ND & 17.49 & 104.15 \\
\hline 11109 & Prill 4 & 2.93 & ND & 0.34 & 1.06 & 0.47 & 0.28 & 3.16 & 72.55 & ND & 19.20 & 104.59 \\
\hline 11109 & Prill 5 & 2.07 & ND & ND & 0.29 & 0.27 & ND & 2.45 & 75.47 & ND & 19.45 & 102.54 \\
\hline 11109 & Prill 6 & 2.15 & ND & ND & 0.25 & ND & ND & 2.32 & 74.88 & ND & 20.39 & 103.63 \\
\hline 11109 & Prill 7 & 1.62 & ND & ND & ND & ND & ND & 0.82 & 76.40 & ND & 21.17 & 102.14 \\
\hline 11109 & Prill 8 & 1.65 & ND & ND & 0.21 & ND & ND & 2.51 & 74.21 & ND & 21.43 & 101.96 \\
\hline 11109 & Prill 9 & 1.33 & ND & ND & ND & ND & ND & 0.42 & 75.33 & ND & 22.92 & 101.98 \\
\hline 11109 & Prill 10 & 1.44 & ND & ND & 0.16 & ND & 0.24 & 2.39 & 71.71 & ND & 24.06 & 102.80 \\
\hline
\end{tabular}

$N D$ not detected

cuprite droplets or crystallising as delafossite needles. It was suggested that this might denote the following step in the chaine opératoire after smelting: re-melting of the recovered Fe-rich metal, whereby the copper would be refined under oxidising conditions that re-oxidised the Fe. However, it is expected that part of this $\mathrm{Fe}$ also ended in the final object as minor or trace element (Craddock and Meeks 1987).

Previous analyses of copper smelting slags corresponding to a later period of the Neapolis (Renzi et al. 2008; Montero

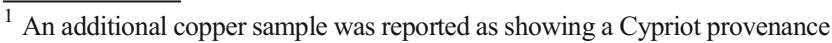
in Montero et al. (2008). Recent re-examinations of the data about the recovery of this find make impossible to confidently relate it to Emporion. Therefore, this result cannot be taken as prove of further Mediterranean connections.
}

Ruiz unpublished data) indicate that the ore case was characterised by $\mathrm{Co}$ impurities. Moreover, $\mathrm{Pb}$ isotope analyses of some copper ingots by Montero-Ruiz et al. (2008) suggested a diversified provenance, including Southern France/ Catalonia. ${ }^{1}$ When integrated with our results for the earlier phase, this panorama points to considerable change and diversification of the copper resources over time. During the early stages of the colony's life, ore acquisition would have been based on indigenous-Greek contacts with groups close to the coast. Later, ingots/ores from further areas might have been acquired at the same time as the colony progressively expanded its influence. Finally, ingots from further Mediterranean territories might have been used when the area was completely integrated into the Mediterranean trading system. 
While the manufacture of ternary leaded bronzes has been reported by Renzi et al. (2008) for later moments, our study only identified the production of binary alloys. Sample 1311B2, the bronze recycling slag, suggests that Greeks had access to the internal trading routes to acquire metallic objects/scrap metal since the very first stages. Probably, these recycled items were indigenous manufactures.

Similar to other Iron Age sites such as La Fonteta (Renzi 2013) or El Castru (Farci et al. 2017), different alloying methods appear to have been used at Emporion. Co-smelting, the method with the longest history and thus best known to the indigenous people, was still in use during IA (samples 1311-B4/5, 1311-A2 and maybe 1171-4). The $\mathrm{Cu}$ ore used in this case does not appear to have the same minor impurities as that used for copper smelting (samples 1215-4 and 1171-2), and it is not rich in Fe oxide (Tables 4 and 9). Although our sample is admittedly very small, the possibility of diverse ores employed depending on the metallurgical operation should be considered in future studies.

Although the use of cementation was not conclusively proved by this set of analyses, it does appear likely (sample 1171-4). Renzi et al. (2008) also suggested the use of a cementation process to produce a ternary alloy in later phases of the site, thus showing that this technique, also known by indigenous people, continued in use and probably co-existed with the other alloying methods.

Finally, sample 11109-1 encapsulates an alloying process based on the mixture of metallic tin and copper. Finding this evidence in a context related to the first occupational level of the Neapolis reinforces Rovira's (2007) proposal that this innovation was brought by Mediterranean peoples. It is tempting to connect the Fe-rich bronze in this sample to the copper smelted at the site, but the actual source of the metal needs to be confirmed. While the evidence for co-melting in the South may be attributed to the Phoenician colonisation, its occurrence in Emporion indicates the Greeks were knowledgeable of this technique too and facilitated its transfer to Iberia. Having said this, not all sites influenced by Mediterranean colonisations should be automatically linked with the knowledge of the newest alloying technique. As a case in point, at Sant Jaume - Mas d'en Serra (Tarragona), a site dated to the late seventh to early sixth century BC that was heavily influenced by the Phoenician trade, only cementation has been confirmed for now (Gracia and García 1999; Rovira 2007).

The co-existence of a variety of bronze making methods, at Emporion and elsewhere (see the "Copper and tin bronze production techniques: Iberia is different" section), compels us to start hypothesising the factors that would have influenced the choice of one technique over another in different contexts (Table 11). More focused research should be devoted to this matter, including additional experiments to assess their relative efficiency and diagnostic markers. We will only attempt to offer a few pointers here based on the previous works mentioned in the "Copper and tin bronze production techniques: Iberia is different" section of this paper and the new evidence reported here. We aim to show how the preliminary evidence from Emporion as a case study starts informing these views once contextualised in the reality of the North-east, thus highlighting the potential of this area for further studies.

The acquisition of metallic Sn at Emporion may have been dependent on external Mediterranean contacts, given the absence of evidence for tin smelting at the site (and Iberia more broadly) until later moments of the IA at Castro de Carvalhelhos (Portugal) (see supra) (Figueiredo et al. 2018). Cassiterite might have been locally available at the

Table 11 Different variables that might have affected the selection of a specific alloying technique at Emporion

\begin{tabular}{|c|c|c|}
\hline Constraint & Choice & Possible explanation \\
\hline \multirow{2}{*}{$\begin{array}{l}\text { Availability of imported } \\
\text { metallic Sn }\end{array}$} & Available: co-melting & Best control of the alloy and its quality although more charcoal is needed. \\
\hline & Not available: co-smelting or cementation & The general recovery of $\mathrm{Sn}$ using $\mathrm{SnO}_{2}$ was efficient enough for the demand. \\
\hline \multirow[t]{2}{*}{$\begin{array}{l}\text { Availability of metallic } \\
\mathrm{Cu} \text { or bronze }\end{array}$} & Available: cementation or co-melting & $\begin{array}{l}\text { It can come from a previous } \mathrm{Cu} \text { smelting or recycling operation or } \\
\text { Mediterranean contacts. }\end{array}$ \\
\hline & Not available: co-smelting & $\begin{array}{l}\text { Very unlikely that this was a key variable for choosing co-smelting given the } \\
\text { contiguous } \mathrm{Cu} \text { smelting activities. }\end{array}$ \\
\hline \multirow{2}{*}{$\begin{array}{l}\text { Availability of a } \\
\text { high-quality } \mathrm{Cu} \text { ores }\end{array}$} & Available: co-smelting? & No need to refine out ore impurities. Assumption based on scarce evidence. \\
\hline & Not available: cementation or co-melting & Two stages required in order to refine copper before proceeding to alloying. \\
\hline \multirow[t]{2}{*}{ Charcoal } & $\begin{array}{l}\text { No supply problems: cementation or } \\
\text { co-melting }\end{array}$ & $\begin{array}{l}\text { Implies two operations ( } \mathrm{Cu} \text { smelting and alloying) and higher charcoal } \\
\text { consumption. }\end{array}$ \\
\hline & Supply problems: co-smelting, recycling & Implies a single operation. \\
\hline \multirow[t]{2}{*}{ Time and labour available } & Available: cementation or co-melting & Implies two operations (assuming using $\mathrm{Cu}$ smelted at the site). \\
\hline & Not available: co-smelting or recycling & Implies a single operation. \\
\hline \multirow{2}{*}{$\begin{array}{l}\text { Desired quality of the } \\
\text { product }\end{array}$} & Very good quality: co-melting & Allows good control of the alloy produced. \\
\hline & $\begin{array}{l}\text { No big quality concerns: co-smelting, } \\
\text { cementation or recycling }\end{array}$ & Do not allow very good control of the alloy composition. \\
\hline
\end{tabular}


mineralisation at Creus Cape and other tin-bearing minerals have been also documented for the broader north-eastern area (Martín Cólliga et al. 1999; Soriano 2013, p. 59). Mediterranean trade of Sn minerals has also been suggested based on the evidence of cassiterite found at Bajo de la Campana shipwreck (Renzi 2013) and of metallic tin (43.2 kg of metal as an ingot and melted residues) at Cala Sant Vicenç shipwreck. The latter is thought to be a Greek shipwreck dated to the end of the sixth century BC, in the context of the expansion of the Phocaean trading routes supported by Emporion (Rovira 2008; Rovira et al. 2008).

Considering the established tradition of smelting of various metals in Iberia, it is unlikely that the absence of tin smelting at Emporion was due to a lack of technical knowledge. As such, the fact that metallic Sn was used for alloying only when it came 'ready smelted' from abroad may be related to considerations of efficiency. Even though the slag produced by alloying with cassiterite is often richer in Sn (see Table 9; Table 2 in Farci et al. 2017; Rovira 2007), it is generally accepted that a one-step process is likely to have been more efficient in terms of Sn recovery (Charles 1978). The use of metallic Sn implies potential oxidative Sn losses in two separate steps: during smelting and during alloying, particularly at the rudimentary installations employed at Emporion. Using cassiterite directly also meant burning less charcoal.

If the preference for cassiterite alloying was based on efficiency concerns, this would indicate the existence of appropriate technological knowledge and experience to make this choice. At the same time, this attitude would seem to stand in contrast to the rather inefficient techniques consistently employed to smelt copper (as exemplified in this case by samples 1215-4 and 1171-2). Here, however, it may be appropriate to consider that copper availability may have been less restricted: the Emporitan area is rich in $\mathrm{Cu}$ ores, and the indigenous trading routes could provide scrap metal to re-melt. Higher copper losses could be afforded, explaining the $\mathrm{Cu}$ losses observed in Table 4, and therefore, the alloying technique was probably not selected based on the maximum recovery of copper. As such, the choice of metallic copper vs copper ore would most likely be dictated by other parameters (Table 11). At the same time, alloying based on pure metals (co-melting) would allow better control of the composition of the resulting alloy, and this may have been an important parameter when preparing alloys for objects that demanded specific material properties.

Overall, the flexibility in the extractive techniques documented at the site should be related to variable constraints in the acquisition of resources and an assessment of the costs and benefits of each process, which must also have considered the particulars of demand. A balance was needed between the availability of raw materials/supplies, the investment of labour needed, the cost of the operation and a satisfactory result that met the social and technical expectations. We can therefore hypothesise that rational choices (sensu Godelier 1972) were made and that the choice of each technique is evidence of a good understanding of the operations and of the desired product. Thus, alloying choices responded both to technological constraints (e.g. general recovery of Sn using cassiterite vs. metallic $\mathrm{Sn}$ ) and to socio-cultural dynamics (e.g. quality concerns, Mediterranean trading networks).

This way of thinking can also be applied to copper metallurgy. The evidence for iron smelting at the site indicates that more sophisticated smelting infrastructure (Figs. 2 and 3) were within their technical reach, but simple pits were the rule for copper smelting. The operations were not very efficient in terms of copper recovery (Table 4), but there was no need to invest more because they were cost-effective. "Make it as simple as you can afford it" is a common feature of indigenous metallurgy in Iberia until Roman times, and the evidence at the Greek colony may well respond to a similar rationale.

Of course, these are only initial ideas stimulated by this research that should be explored further, particularly by investigating any possible correlation between bronze making technologies, contexts and artefact types. However, we would caution against any easy assumptions of undeveloped technological knowledge. Strands of evidence such as the already mentioned iron furnaces, or the possible selection of specific temper types for technical ceramics (samples 1311-B4/5 and 1311-B2), altogether suggest that Emporitan metallurgists understood the different technological choices at their disposal and their implications.

The absence of evidence for manufacturing steps such as metal casting (no movable crucibles or moulds found) makes it difficult to assess the product of the smelting and alloying activities: ingots or objects. For later moments at the Neapolis, a complex mould has been reported by Renzi et al. (2008), indicating the production of copper-based objects.

Be that as it may, this workshop model, where copper/ bronze and iron were worked together in the same spaces (see the "The archaeological contexts" section above), expanded to the inner areas of Iberia from the fifth century BC onwards, associated with the spread of iron smelting and smithing technologies (Junyet 1992; Rovira et al. 2003; Martín Ortega et al. 2008). In light of this study, we should see these workshops as key spaces for knowledge transmission not only of iron technology but also of the alloying method consisting of mixing metallic tin and copper. According to our hypothesis, this technique would only be feasible in those areas where the acquisition of metallic tin was possible through Mediterranean contacts. Possibly, inner areas could not supply themselves with imported metallic tin and they continued to use the traditional cementation and co-smelting methods. In relation to the particular case of Emporion, this could be proved by further analyses of materials from the nearby and contemporaneous settlements of Mas Castellar (Pontós), Illa d'en Reixac and Puig de Sant Andreu (Ullastret). This on-going research will clarify the spread of 
co-melting in the Emporitan area in connection to the sociocultural dynamics of the time to assess the real technological impact of Emporion once its influence expanded.

Much further work needs to be done in the future. It would be pertinent to expand the scale of analysis both chronologically and geographically. This will help us assess the development of copper and bronze manufacture (including the appearance of ternary alloys), as well as their relationship to other metallurgical technologies such as silver cupellation and iron smelting. Moreover, a solid experimental archaeology approach that recreates these alloying techniques would shed light on efficiency considerations that will inform the interpretations of our archaeological finds.

This combined approach will allow us to understand this adaptability of the chaines opératoires over time and on a larger scale to really understand how technological and socio-economic dynamics are affecting the local production scale, for example, in influencing the metallurgists' decisions for alloying pathways. If we can characterise these factors in detail in a given area (e.g. north-eastern Iberia), we will be able to develop a model of innovation and adaptation to be ground-truthed in other study areas.

Acknowledgements The analytical work presented in this paper was carried out by JML as part of her MSc dissertation at the UCL Institute of Archaeology, while enjoying a bursary from the Institute for ArchaeoMetallurgical Studies. We are grateful to Agnese Benzonelli and Tom Gregory at the UCL Wolfson Archaeological Science laboratories for technical support. We would also like to thank the two anonymous reviewers that commented on the original version of this paper for their suggestions.

Open Access This article is licensed under a Creative Commons Attribution 4.0 International License, which permits use, sharing, adaptation, distribution and reproduction in any medium or format, as long as you give appropriate credit to the original author(s) and the source, provide a link to the Creative Commons licence, and indicate if changes were made. The images or other third party material in this article are included in the article's Creative Commons licence, unless indicated otherwise in a credit line to the material. If material is not included in the article's Creative Commons licence and your intended use is not permitted by statutory regulation or exceeds the permitted use, you will need to obtain permission directly from the copyright holder. To view a copy of this licence, visit http://creativecommons.org/licenses/by/4.0/.

\section{References}

Alcalde G, Molist M, Montero I, Planagumà L, Saña M, Toledo A (1998) Producciones metalúrgicas en el Nordeste de la Península Ibérica durante el III milenio cal. AC: El taller de la Bauma del Serrat del Pont (Tortellà, Girona). Trab Prehist 55(1):81-100

Aquilué X, Castanyer P, Santos M, Tremoleda J (2010) Grecs et indigènes aux origines de l'enclave phocéenne d'Emporion. In: Tréziny H (ed) Grecs et indigènes de la Catalogne à la mer Noire. Actes des rencontres du programme européen Ramses 2 (20062008) ), Centre Camille Jullian. BiAMA 3. Aix-en-Provence Paris, pp 65-78
Aquilué X, Castanyer P, Santos M, Tremoleda J (2011) Resultats de les darreres intervencions arqueològiques a la Neàpolis de la ciutat grega d'Empòrion (Empúries, l'Escala, Alt Empordà). Tribuna d'Arqueologia 2009:121-147

Aquilué X, Castanyer P, Santos M, Tremoleda J (2012) El paisatge funerari en el territori d'Empúries, entre el Bronze Final i la primera edat del Ferro. In: Rovira Hortalà MC, López Cachero FJ, Mazière F (dir) Les necròpolis d'incineració entre l'Ebre i el Tíber (segles IXVI a.C.). Monografies 14, MAC. Barcelona, pp 75-90

Bachmann H (1982) The identification of slags from archaeological sites. Institute of Archaeology, London

Castanyer P, Santos M, Tremoleda J (2009-2011) Darreres recerques sobre la gènesi de l'enclavament grec d'Empòrion. Empúries 56: $55-73$

Castanyer P, Santos M, Tremoleda J (2015) Nuevos datos arqueológicos sobre la evolución urbana de Emporion. In: Roure R (ed) Contacts et acculturations en Mediterranée occidentale: Hommages à Michel Bats. Actes du colloque d'Hyères 15-18 septembre 2011. BiAMA 15, Études Massaliètes 12. Errance, Paris, pp 121-130

Castanyer P, Santos M, Tremoleda J, Julià R, Montaner J, Riera S (2017) Evolución del paisaje y del poblamiento del territorio de EmporionEmporiae entre el Bronce Final y la Antigüedad Tardía. Madrider Mitteilungen 57:306-361

Charles JA (1978) The development of the usage of tin and tin-bronze: some problems. In: Olin JS, Wertime TA (eds) Franklin AD. The search for ancient tin, Washington, pp 25-32

Craddock PT, Meeks ND (1987) Iron in ancient copper. Archaeometry19/2:187-204

Dungworth D (2000) A note on the analysis of crucibles and moulds. Hist Metall 34(2):83-86

Erb-Satullo NL, Gilmour BJJ, Khakhutaishvili N (2015) Crucible technologies in the Late Bronze - Early Iron Age South Caucasus: copper processing, tin bronze production, and the possibility of local tin ores. J Archaeol Sci 61:260-276

Farci C, Martinón-Torres M, González-Álvarez D (2017) Bronze production in the Iron Age of the Iberian Peninsula: the case of El Castru, Vigaña (Asturias, NW Spain). J Archaeol Sci Rep 11:338-351

Fernández Miranda M (1994) La Edad del Bronceen la Mancha Oriental. In: Diputación Provincial de Toledo (ed.) La Edad del Bronce en Castilla la Mancha; actas del Simposio, 1990, pp 243-290

Fernandez-Posse MD, Montero I, Sanchez-Palencia FJ, Rovira S (1993) Espacio y metalurgia en la cultura castreña: la zona arqueológica de las Médulas. Trab Prehist 50:197-220

Figueiredo E, Silva RJC, Senna-Martínez JC, Araújo MF, Braz Fernandes FM, Inês Vaz JL (2010) Smelting and recycling evidences from the Late Bronze Age site of Baiões (Viseu, Portugal). J Archaeol Sci 37:1623-1634

Figueiredo E, Fonte J, Lima A, Veiga JP, Silva RJC, Mirão J (2018) Ancient tin production: slags from the Iron Age Carvalhelhos hillfort (NW Iberian Peninsula). J Archaeol Sci 93:1-18

Freestone IC (2001) Port-depositional changes in archaeological ceramic and glasses. In: Brothwell DR, Pollard AM (eds.) Handbook of archaeological science. John Wiley \& Sons Ltd, pp 616-625

Freestone IC, Tite MS (1986) Refractories in the ancient and preindustrial world. In: KingeryWD (ed.) High technology ceramics past, present and future: the nature of innovation and change in ceramics technology. Ceramics and civilisation volume III. The American Ceramic Society, Westerville, pp 35-63

Godelier M (1972) Rationality and irrationality in economics. Monthly Review Press, New York

Gómez Ramos P (1996) Hornos de reducción de cobre y bronce en la pre y protohistoria de la Península Ibérica. Trab Prehist 53(1):127-143

González de Canales F, Serrano L, Llompar J (2006) The pre-colonial Phoenician Emporium of Huelva ca 900-770 BC. BA Besh 81:13-29

Gracia F, García D (1999) La primera fase del poblamiento protohistórico en el área sur de la desembocadura del Ebro. El poblado fortificado 
de Sant Jaume - Mas d'en Serra (Alcanar), campañas 1997-1998. Revista d'Arqueologia de Ponent 9:131-155

Hauptmann A (2007) The archaeometallurgy of copper. Evidence from Faynan, Jordan. Springer, New York

Junyet E (1992) Els orígens del ferro a Catalunya. Revista d'Arqueologia de Ponent 2:21-35

Kearns T, Martinón-Torres M, Rehren T (2010) Metal to mould: alloy identification in experimental casting moulds using XRF. Hist Metall 44(1):48-58

López Cachero FJ (2007) Sociedad y economía durante el Bronce Final y la primera Edad del Hierro en el noreste peninsular: una aproximación a partir de las evidencias arqueológicas. Trab Prehist 64(1):99-120

Mar R, Ruiz de Arbulo J (1993) Ampurias romana, Historia, arquitectura y arqueología. Ausa, Sabadell

Martín Cólliga A, Gallart Fernández J, Rovira Hortalà C, Mata-Perelló J (1999) Nordeste. In: Delibes de Castro G, Montero Ruiz I. (coord.) Las primeras etapas metalúrgicas en la Península Ibérica. II Estudios regionales. Instituto Universitario Ortega y Gaset, Madrid, pp 115-177

Martín Ortega A, Plana Mallart R, Codina Falgàs F, Gay C (2008) El jaciment Cam d'en Gou-Gord d'en Batlle, un barri periurbà de l'oppidum d'Ullastret (Baix Empordà). Cypsela 17:161-183

Martinón-Torres M, Rehren T (2014) Chapter 6: technical ceramics. In: Roberts BW, Thornton CP (eds) Archaeometallurgy in global perspective. Springer Science + Business Media, New York, pp 107-130

Milton C, Dwornik EJ, Finkelman RB, Toulmin III P (1976) Slags from an ancient copper smelter at Timna, Israel. Journal of the Historical Metallurgy Society 10:24-33

Montero Ruíz I, Gornés Hachero JS, de Nicolás MJ, Gual Cerdó J (2005) Aproximación a la metalurgia prehistórica de Menorca entre el 2000 y el 650 cal AC. Mayurqa 30:289-306

Montero-Ruiz I, Gener M, Hunt M, Renzi M, Lloréns R (2008) Caracterización analítica de la producción metalúrgica protohistórica de plata en Cataluña. Revista de Arqueología de Ponent 18:292-316

Montes-Landa, J (2017) Archaeo-metallurgical study of Iron Age samples from Emporion (L'Escala, Spain). MSc dissertation. UCL Institute of Archaeology

Müller R, Rehren T, Rovira S (2004) Almizaraque and the early copper metallurgy southeast Spain: new data. Madriden Mettelungen 45:33-56

Murillo-Barroso M, Pryce TO, Bellina B, Martinón-Torres M (2010) Khao Sam Kaeo - an archaeometallurgical crossroad for transasiatic technological traditions. J Archaeol Sci 37:1761-1772

Murillo-Barroso M, Martinón-Torres M, Camalich Maddieu MD, Martín Socas D, Molina González F (2017) Early metallurgy in SE Iberia. The workshop of Las Pilas (Mojácar, Almería, Spain). Archaeol Anthropol Sci 9(7):1539-1569

Nieto X, Revil A, Morhange C, Vivar G, Rizzon E, Aguelo X (2005) La fachada marítima de Ampurias: estudios geofísicos y datos arqueológicos. Empúries 54:71-100

Nothover P (1987) Non-ferrous metallurgy. In: Cunliffe B (ed) Hengisbury Head, Dorset. Volume I: The Prehistoric and Roman settlement, 3500BC-AD500. OUCA Monograph no13, Oxford University Committee for Archaeology, Oxford, pp 186-196

Pigott VC, Rogers HC, Nash SK (2003) Archaeometallurgical investigations at Malyan. In: Miller NF, Abdi K (eds) Essays on the archaeology of Iran in honor of William M. Summer. Institute of Archaeology. University of California, California, pp 161-175

Polzer ME, Pinedo Reyes J (2009) Phoenician rising: excavations of the Bajo de la Campana site begins. The INA Annual 2008:5-10

Rademakers FW, Farci C (2018) Reconstructing bronze production technology from ancient crucible slag: experimental perspectives on tin oxide identification. J Archaeol Sci Rep 18:343-355

Rademakers FW, Rehren T (2016) Seeing the forest for the trees: assessing technological variability in ancient metallurgical crucible assemblages. J Archaeol Sci Rep 7:588-596
Rademakers FW, Rehren T, Pusch E (2018) Bronze production in PiRamesse: alloying technology and material use. In: Ben-Yosef E, Goren Y (eds.) Mining for copper: essays in honor of Professor Beno Rothenberg

Renzi M (2013) La Fonteta (Guardamar del Segura, Alicante) y la metalurgia fenicia de época arcaica en la Península Ibérica. $\mathrm{PhD}$ Thesis, Universidad Complutense de Madrid

Renzi M, Montero-Ruiz I, Rovira-Lloréns S, Gener M, Rovira-Hortalà C, Hunt M, Santos-Retolaza M (2008) Actividades metalúrgicas en Ampurias (L'Escala, Girona, España). In: Rovira Lloréns S, García-Heras M, Gener Moret M, Montero Ruiz I (eds.) Actas VII congreso ibérico de arqueometría. Madrid, 8-10 de octubre de 2007. Madrid, pp 468-478

Rodríguez Díaz A, Pavón Solde Vila I, Merideth C and Tresserras J (2001) El Cerro de San Cristóbal, Logrosán, Extremadura, Spain: the archaeometallurgical excavation of a Late Bronze Age tin-mining and metal working site. BAR International Series 922, Oxford

Roldán Bernal B, Martín Camino M, Pérez Bonet MA (1995) El yacimiento submarino del Bajo de la Campa. In: Ministerio de Cultura (ed.) Cuadernos de Arqueología Marítima 3. Madrid, pp 11-62

Rovira S (2007) La producción de bronces en la Prehistoria. In: Molerai Marimon J, Farjasi Silva J, Rourai Grabulosa P, Pradelli Cara T (eds) Avances en Arqueometría 2005. Actas VI Congreso Ibérico de Arqueometría. Universitat de Girona, Girona, pp 21-35

Rovira C (2008) El carregament d'estany. In: Nieto X, Santos M (eds) El vaixell grec arcaic de Cala Sant Vicenç, Monografies del CASC 7. Girona, pp 238-241

Rovira Hortalà MC (1993) Metal.lúrgia ibèrica: identificació i interpretació del satuells de reducció i gresols arran de les troballes de l'Illad'en Reixac (Ullastret, Baix Empordà). Cypsela X:61-69

Rovira Lloréns S (2000) Continuismo e innovación en la metalurgia Ibérica. SAGVNTUM-PLAVExtra-3:209-221

Rovira S, Montero I (2003) Natural tin-bronze alloy in Iberian Peninsula metallurgy: potentiality and reality. In: Giumlia-MairA, Lo Schiavo $\mathrm{F}$ (eds.) Le problem de l'ètain à l'origine de la métallutgie. The problem of early tin. BAR International Series, Oxford, pp 15-22

Rovira S, Montero-Ruiz I (2013) Iberia: technological developments of metallurgy. In: Burmeister S, Hansen S, Kunst M, Müller-Scheeßel $\mathrm{N}$ (eds.) Metal matters. Innovative technologies and social change in Prehistory and antiquity. Berlin, pp 231-239

Rovira S, Renzi M (2017) Early technologies for metal production in the Iberian Peninsula. Mater Manuf Process 32(7-8):756-764

Rovira MC, Pons E, Martín MA (2003) Metallurgical production in Catalonia (N.E. Spain) during the Iron Age: technical and social significance. In: Archaeometallurgy in Europe. 24, 25, 26 September 2003. Milan, Italy. Proceedings, vol.2.AssociazioneItaliana di Metallurgia, Milano, pp 185-197

Rovira C, Rovira, S, Montero I, Pernicka E, (2008) Caracterització analítica dels materials metàl-lics. In: Nieto X, Santos M (eds) El vaixell grec arcaic de Cala Sant Vicenç, Monografies del CASC 7. Girona, pp 403-411

Santos Retolaza M (2003) Fenicios y griegos en el extremo N.E. peninsular durante la época arcaica y los orígenes del enclave foceo de Emporion. In: Costa B, Fernández JH (eds.) Contactos en el extremo de la oikouméne. Los griegos en occidente y sus relaciones con los fenicios. XVII Jornadas de Arqueología fenicio-púnica (Eivissa, 2002). Govern de les Illes Balears, Eivissa, pp 87-132

Santos M, Castanyer P, Tremoleda J (2013) Emporion arcaica: los ritmos y las fisonomías de los dos establecimientos originarios, a partir de los últimos datos arqueológicos. In: Bouffier S, Hermary A (coords.) L'Occident Grec de Marseille à Mégara Hyblaea. Biblioteque d'Archéologie Méditerranéenne et Africaine 13.Errance, Arles, pp 103-113

Soriano I (2013) Metalurgia y sociedad en el Nordeste de la Península Ibérica (finales del IV-II mil.cal. ANE). Archaeopress, Oxford 
Soriano I, Escanilla N (2016) Can Mur (Barcelona). Crisoles con sistema de prensión y la metalurgia de la Edad del Bronce en el nordeste de la Península Ibérica. Trab Prehist 73:160-179
Publisher's note Springer Nature remains neutral with regard to jurisdictional claims in published maps and institutional affiliations. 